\title{
Czy wszystkie preparaty toksyny botulinowej typu A sq takie same? Porównanie trzech preparatów toksyny botulinowej typu A w zarejestrowanych wskazaniach w neurologii
}

\author{
Are botulinum toxin type A preparations really the same medication? \\ A comparison of three botulinum toxin A formulations in labelled neurological indications
}

Jarosław Sławek1,2, Halina Car ${ }^{3}$ Marcin Bonikowski, Andrzej Boguckij, Dariusz Koziorowskib, Anna Potulska-Chromik7, Monika Rudzińska8

IZakład Pielęgniarstwa Neurologiczno-Psychiatrycznego, Gdański Uniwersytet Medyczny

${ }^{2}$ Szpital Specjalistyczny św. Wojciecha w Gdańsku

${ }^{3}$ Zakład Farmakologii, Uniwersytet Medyczny w Białymstoku

${ }^{4}$ Mazowieckie Centrum Neuropsychiatrii i Rehabilitacii Dzieci i Młodzieży w Zagórzu k. Warszawy

${ }^{5}$ Klinika Chorób Układu Pozapiramidowego, Uniwersytet Medyczny w Łodzi

${ }^{6}$ Klinika Neurologii, Wydział Nauki o Zdrowiu, Uniwersytet Medyczny w Warszawie

${ }^{7}$ Klinika Neurologii, Uniwersytet Medyczny w Warszawie

${ }^{8}$ Klinika Neurologii, Uniwersytet Jagielloński, Collegium Medicum w Krakowie

Neurologia i Neurochirurgia Polska 2010; 44, 1: 43-64

\section{Streszczenie}

W ostatnim czasie lista klinicznych zastosowań toksyny botulinowej typu A (BTX-A) znacznie się wydłużyła. Substancja ta stała się narzędziem w rękach neurologów, lekarzy rehabilitacji, urologów, proktologów, migrenologów czy kosmetologów. Zwiększyła się także liczba produkowanych preparatów BTX-A. Obecnie na rynku dostępne są preparaty: Botox, Dysport i Xeomin. Mają one podobny mechanizm działania, aczkolwiek różnią się istotnie budową chemiczną, siłą działania, migracją poza miejsce podania, skutecznością i profilem działań niepożądanych. Te odrębności mogą sprawiać trudności w ich zamiennym stosowaniu przez niedoświadczonego lekarza. Rodzą także pytania o ich równowartość ekonomiczną. Autorzy dokonali przeglądu prac i porównali dostępne preparaty w zarejestrowanych w Polsce wskazaniach neurologicznych. Preparaty te powinny być traktowane jako odrębne leki, a ich zastosowanie kliniczne oparte o dane z badań klinicznych dotyczących poszczególnych preparatów.

\begin{abstract}
Recently, the list of clinical applications of botulinum toxin type A (BTX-A) enlarged. This medication is used not only by neurologists, but also by medical rehabilitation specialists, urologists, proctologists, and migraine and aesthetic medicine specialists. Currently, there are three commercially available BTX-A preparations available: Botox, Dysport and Xeomin. They have similar mechanisms of action but their chemical formulation, clinical potency, migration and diffusion as well as safety profile seem to be different. This may result in problems of bioequivalence, not only clinical but also economic ones. The authors reviewed the available clinical and laboratory studies on neurological indications labelled in Poland. Each BTX-A formulation should be treated as a different medication and used cautiously according to the individual range of dosages established in clinical trials.
\end{abstract}

Key words: botulinum toxin, dystonia, spasticity, cerebral palsy.

Słowa kluczowe: toksyna botulinowa, dystonie, spastyczność, mózgowe porażenie dziecięce.

Adres do korespondencii: dr hab. med. Jarosław Sławek, Zakład Pielęgniarstwa Neurologiczno-Psychiatrycznego, Gdański Uniwersytet Medyczny, Szpital Specjalistyczny św. Woiciecha, Al. Jana Pawła II 50,80-462 Gdańsk, e-mail: jaroslawek@gumed.edu.pl Pracę otrzymano: 22.09.2009; przyięto do druku: 27.11.2009 


\section{Wstęp}

Toksyna botulinowa typu A (BTX-A) jest obecna na rynku farmaceutycznym od 20 lat. Pierwszym preparatem zarejestrowanym do leczenia zeza i kurczu powiek, wkrótce potem także dystonii szyjnej, był Botox amerykańskiej firmy Allergan (1989), znany wcześniej pod nazwą Oculinum. Kolejno, w 1991 r. brytyjska firma Porton (potem Speywood) wprowadziła w podobnych wskazaniach preparat Dysport, który następnie został zakupiony przez francuską firmę Ipsen. Rozwój wiedzy na temat immunogenności i związanej z nią wtórnej oporności na leczenie u części chorych leczonych przewlekle BTX-A był powodem wprowadzenia na rynek przez firmę Elan (obecnie własność firmy Solistice) innego serotypu toksyny (typ B) o nazwie handlowej Myobloc (USA) lub NeuroBloc (Europa). W 2000 r. niemiecka firma Merz wprowadziła na rynek preparat BTX-A pozbawiony białek kompleksujących, o nazwie handlowej Xeomin. W różnych krajach na świecie produkowane są również preparaty BTX-A, które nie są przebadane wg przyjętych dzisiaj w medycynie standardów (np. produkowane i stosowane lokalnie, ale również dystrybuowane do innych krajów preparaty z Chin czy Korei). Obecnie na polskim rynku zarejestrowane są trzy preparaty BTX-A: Botox, Dysport i Xeomin.

Tak dynamiczny rozwój rynku toksyn botulinowych spowodowany jest poznaniem nowych mechanizmów ich działania, a co za tym idzie - nowych wskazań do ich stosowania w praktyce klinicznej. Mechanizmy te obejmują: obniżanie napięcia mięśni prążkowanych (dystonie ogniskowe, segmentalne, połowiczy kurcz twarzy, spastyczność, medycyna estetyczna) i gładkich (achalazja przełyku, szczelina odbytu, pęcherz neurogenny), wpływ na pozazwojowe zakończenia cholinergiczne w gruczołach potowych (nadpotliwość) i ślinowych (nadmierne ślinienie) oraz działanie przeciwbólowe (napięciowe bóle głowy, migrena, ból neuropatyczny).

Takk gwałtowny rozwój wskazań spowodował, że BTX-A stała się narzędziem w rękach nie tylko neurologów, ale także lekarzy innych specjalności. Liczne z wymienionych wskazań nie uzyskały (mimo powszechności stosowania) rejestracji i lek jest używany w systemie tzw. offlabel. W niektórych zarejestrowanych wskazaniach toksyny używa się w innych niż zarejestrowane grupach mięśniowych bądź w innych, zwykle większych, dawkach (np. mózgowe porażenie dziecięce). To szerokie stosowanie leku oraz pojawienie się różnych preparatów
BTX-A na rynku wywołało dyskusję na temat różnic i podobieństw między nimi oraz sposobów wymiennego ich stosowania. Różnice dotyczą budowy chemicznej (zawartości białek, ilości toksyny w fiolce), siły działania w modelu zwierzęcym i w różnych wskazaniach klinicznych, zdolności do dyfuzji z miejsca podania, profilu działań niepożądanych, a w końcu przeliczania dawek przy przechodzeniu z jednego preparatu na drugi oraz - co za tym idzie - kosztów leczenia.

Niebezpieczeństwo rodzi także pojawienie się BTX-A produkowanej lokalnie w różnych krajach. Dla przykładu, na opakowaniu toksyny chińskiej CNBTX-A (Nanfeng) (niezarejestrowana oficjalnie w żadnym kraju) dawkę określono na 55 j. - w rzeczywistości siła działania leku zawartego w jednej ampułce tego leku równa jest sile działania $243 \mathrm{j}$. leku zawartego w ampułce preparatu Botox, co może być przyczyną poważnych w skutkach pomyłek [1].

Wszystko to stało się przyczyną, dla której autorzy niniejszej publikacji postanowili w sposób systematyczny przyjrzeć się dostępnym preparatom BTX-A pod kątem różnic między nimi zarówno na poziomie laboratoryjnym, jak i klinicznym. Przegląd przeprowadzono na podstawie analizy badań klinicznych, szczególnie tych, które były podstawą rejestracji w danym wskazaniu bądź odnosity się do porównań poszczególnych preparatów w badaniach laboratoryjnych i klinicznych, a także najważniejszych artykułów przeglądowych na ten temat dzięki danym dostępnym w bazie PubMed/Medline.

\section{Porównanie preparatów pod względem budowy chemicznej oraz siły działania i dyfuzji w modelach zwierzęcych}

Wszystkie dotychczas zarejestrowane preparaty BTX-A są lekami biologicznymi. Istotne różnice dotyczące ich struktury i wielkości cząsteczki, parametrów farmakokinetycznych, np. migracji poza miejsce podania, a także bezpieczeństwa stosowania i efektywności wskazują, że nie są one równoważne.

\section{Budowa preparatów}

Naturalnie występująca toksyna typu A zawiera białko toksyny BTX-A (polipeptyd o znanej sekwencji aminokwasów), które ma budowę dwułańcuchową - łańcuch lekki (ok. $50 \mathrm{kD}$ ) połączony z ciężkim (ok. $100 \mathrm{kD}$ ) pojedynczym wiązaniem dwusiarczko- 
wym oraz białka nietoksyczne. Zarejestrowane preparaty zawierają BTX-A pochodząca z odmiennych szczepów bakterii Clostridium botulinum (tab. 1.), co spowodowało rozróżnienie 4 podtypów - od A1 do A4. Podtypy różnią się składem aminokwasów w mniej niż $16 \%$ [2] i te odmienności warunkują inne wiązania toksyn A do monoklonalnych przeciwciał antyBTX-A [3]. Ważne różnice budowy preparatów dostępnych w Polsce (Botox, Dysport i Xeomin) przedstawiono w tab. 1.

Jednostki aktywności biologicznej, czyli jednostki $\mathrm{LD}_{50}$ (nie jednostki międzynarodowe), poszczególnych BTX-A są indywidualne dla każdego preparatu i uzyskano je, określając ilość toksyny każdego preparatu podanej dootrzewnowo, która jest wymagana do uśmiercenia 50\% populacji samic myszy Swiss Webster o masie 18-20 g. Nie są one jednakowe dla zarejestrowanych leków zawierających BTX-A, a wynika to z różnych metod produkcji leków biologicznych (nie odtwór(zych) i dlatego nie można ich stosować zamiennie. Bezpośrednie porównanie mocy preparatów BTX-A jest niemożliwe również ze względu na różnice w składzie leków i warunkach doświadczeń laboratoryjnych. Z tego powodu podaje się zakres dawek określonej BTX-A stosowanych w danych jednostkach chorobowych, a nie biorównoważniki dawek [4], a kryterium wyboru preparatu do terapii jest nie liczba jednostek leku w opakowaniu, ale wskazania i właściwości farmakologiczne konkretnego preparatu.

Leki zawierające BTX-A mają różną masę cząsteczkową, zależną od obecności białek towarzyszących. Preparat Botox o masie $900 \mathrm{kD}$ odpowiada wielkości toksyny występującej naturalnie. Dysport ma masę cząsteczkową heterogenną powyżej $500 \mathrm{kD}$, ponieważ zawiera nie- wielką ilość kompleksu 900 kD i BTX-A pomiędzy $500 \mathrm{kD}$ i $700 \mathrm{kD}$ [5]. Xeomin zawiera tylko BTX-A o masie $150 \mathrm{kD}$ bez towarzyszących białek. Preparaty te różnią się także pod względem zawartości ilościowej białka toksyny, co ma znaczenie we właściwym przygotowaniu rozcieńczeń roztworu do podania. Większa objętość leku nadmiernie rozcieńczonego może spowodować łatwiejszą dyfuzję z miejsca podania, mniejszą efektywność miejscową i nasilenie działań niepożądanych [6].

Oba łańcuchy toksyny uczestniczą w skomplikowanym mechanizmie działania BTX-A - jest on zblizony dla wszystkich preparatów. Odmienności dotyczą wpływu na białko SNAP-25 (synaptosomal associate protein 25) niezbędne do fuzji pęcherzyka synaptycznego zawierającego acetylocholinę z błoną presynaptyczną. Botox i Dysport hydrolizują białko SNAP-25 pomiędzy Gln197-Arg198, natomiast Xeomin pomiędzy Gln198-Arg199, w miejscu charakterystycznym dla toksyny typu C i trypsyny [7]. Różnice te mogą mieć następstwa kliniczne, ale badania na ten temat nie są dostępne. Toksyna botulinowa typu A hamuje uwalnianie acetylocholiny, podstawowego neuroprzekaźnika regulującego aktywność skurczową mięśni, oraz licznych przekaźników transmisji bólu, np. substancji P, CGRP (calcitonin gene related peptide) i glutaminianu [8,9]. Hamuje również uwalnianie ATP ze śluzówki pęcherza moczowego, ogranicza synaptyczną ekspresję receptora TRPV1 (transient receptor potential vanilloid receptors), zmniejsza stężenie NGF (nerve growth factor) [10-12] oraz ekspresję cyklooksygenazy 2 [13]. Obecność nietoksycznych białek towarzyszących: hemaglutyninowych i niehemaglutyninowych, warunkuje właściwą adhezję toksyny do części presynaptycznej złącza nerwowo-mięśniowego, ogranicza jej rozprzestrzenianie poza miejsce

Tabela 1. Porównanie wybranych parametrów preparatów zawierających toksynę botulinową A

Table 1. The comparison of selected characteristics of botulinum toxin type A preparations

\begin{tabular}{|c|c|c|c|}
\hline Parametry/preparaty & Botox & Dysport & Xeomin \\
\hline szczep bakterii/podtyp BTX-A & Hall/A1 & NCTC 2916/? & Hall/A1 \\
\hline liczba jednostek w opakowaniu & 100 & 500 & 100 \\
\hline masa cząsteczkowa $(\mathrm{kDa})$ & 900 & $>500$ & 150 \\
\hline ilość białka neurotoksyny we fiolce & $<5 \mathrm{ng}$ & $12,5 \mathrm{ng}\left(4,35 \mathrm{ng}^{*}\right)$ & $0,6 \mathrm{ng}$ \\
\hline ilość białka aktywnej toksyny & $0,8 \mathrm{ng}$ & $?$ & $0,6 \mathrm{ng}$ \\
\hline składniki dodatkowe & $\begin{array}{c}0,5 \mathrm{mg} \text { 20-procentowej albuminy } \\
0,9 \mathrm{mg} \mathrm{NaCl}\end{array}$ & $\begin{array}{c}\text { 0,125 mg 20-procentowej albuminy } \\
2,5 \mathrm{mg} \text { laktozy }\end{array}$ & $\begin{array}{c}1 \mathrm{mg} \text { 20-procentowej albuminy } \\
4,7 \mathrm{mg} \text { sacharozy }\end{array}$ \\
\hline postać & suszony próżniowo & liofilizowany & liofilizowany \\
\hline bufory & sól fizjologiczna & żelatynowo-fosforanowy & sól fizjologiczna \\
\hline przechowywanie postaci nierozcieńczonej & 3 lata w temperaturze $2-8^{\circ} \mathrm{C}$ & 2 lata w temperaturze $2-8^{\circ} \mathrm{C}$ & 3 lata w temperaturze ponizej $25^{\circ} \mathrm{C}$ \\
\hline
\end{tabular}


podania, a tym samym zmniejsza ryzyko wystąpienia działań niepożądanych, np. porażenia mięśni odległych $[14,15]$. Według innych autorów rolą białek towarzyszących jest równiė̇ stabilizacja struktury BTX-A i ochrona przed jej metabolizmem, który jest bardzo szybki $[16,17]$. Na podstawie badań Hunt i Clarke (2008) oraz Chen i wsp. (1998) brak białek towarzyszących może być przyczyną słabszej wydajności preparatu Xeomin, zwiększonej antygenowości i szybszej degradacji $[1,18]$. Albumina ludzka obecna w preparatach ma stabilizować toksynę, ale może też być przyczyną nadwrażliwości. Sól fizjologiczna jest neutralnym buforem w przypadku dwóch preparatów (Botox i Xeomin). Bufor żelatynowy zawarty w preparacie Dysport może być przyczyną zmiany właściwości adsorpcyjnych i stabilności preparatu oraz zwiększonej antygenowości leku [19]. Wszystkie preparaty BTX-A w formie nierozcieńczonej mają podobne pH wynoszace 7,4. Trwałość preparatów zależy od $\mathrm{pH}$ roztworu (a także $\mathrm{pH}$ środowiska mięśnia, do którego toksyna jest podana, np. obniżenie $\mathrm{pH}$ w stanie zapalnym przyspiesza rozkład BTX-A) i temperatury otoczenia, w którym jest przechowywana. Badania $\mathrm{z}$ użyciem chromatografii cieczowej o wysokiej rozdzielczości wykazały większą stabilność łańcucha lekkiego preparatu Botox niż Xeomin w pH równym 6 lub 7 [20]. Inne badania opisuja jednak trwałość nierozcieńczonego preparatu Xeomin w wysokich temperaturach wynoszącą ok. 3 lat [21]. Wieloośrodkowe badania opisane w pracy Sesardic i wsp. potwierdzają największą stabilność preparatu BOTOX [22]. Z mikrobiologicznego punktu widzenia każdy rozcieńczony preparat zawierający BTX-A powinien być zastosowany natychmiast. Dane dotyczące składu preparatów zawierających BTX-A wskazują na znaczne różnice, co warunkuje odmienne właściwości farmakologiczne wyżej wymienionych leków.

\section{Siła działania}

Siłę działania i bezpieczeństwo stosowania poszczególnych preparatów zawierających BTX-A można obiektywnie przedstawić za pomocą:

- efektywności miejscowej, czyli zwiotczenia mięśni, którą wyraża $\mathrm{ED}_{50}$ (efektywna dawka dla 50\% populacji badanych zwierzą),

- efektywności ogólnoustrojowej mierzonej wartością $\mathrm{LD}_{50}$ (dawka śmiertelna dla $50 \%$ populacji badanych zwierząt) i współczynnika terapeutycznego,

- dyfuzji do mięśni odległych prowadzącej do atrofii i współczynnika dyfuzji.
Ocenę siły działania w badaniach podstawowych podaje się na podstawie efektu chemodenerwacji określonych mięśni po wstrzyknięciu toksyny. W badaniach na zwierzętach rozróżnia się dwie metody oceny efektywności toksyny w miejscu podania - Median Paralysis Unit (MPU) oraz Digit Abduction Score (DAS).

Test MPU jest oparty na zupełnym paralizu tylnej kończyny myszy, spowodowanym wstrzyknięciem toksyny do mięśnia brzuchatego łydki. Używając tej techniki, Pearce i wsp. oszacowali, że 1,0 j. Botoksu odpowiada 4,7 j. preparatu Dysport [23].

Model DAS polega na podaniu BTX-A do głowy mięśnia brzuchatego łydki myszy i ocenie zwiotczenia na podstawie skali rozwarcia pazurów łapy ostrzykniętej w porównaniu z łapą nieostrzykniętą toksyną. W tej metodzie $\mathrm{ED}_{50}$ jest równoznaczne $\mathrm{z}$ osiągnięciem DAS 2. Badania $z$ zastosowaniem DAS pozwoliły na stworzenie krzywej zależności efektu od dawki dla dostępnych preparatów i rankingu preparatów wg $\mathrm{ED}_{50}$ : Botox wykazał najsilniejsze efekty, następna w kolejności była czysta BTX-A 150 (ale nie preparat Xeo$\min )$ i po niej Dysport $\left(\mathrm{ED}_{50}=3,4 \pm 0,3 \mathrm{U} / \mathrm{kg}\right.$ dla Botoksu, 5,7 \pm 0,3 U/kg dla BTX-A 150 i 16,2 \pm 1,1 U/kg dla Dysportu) [24]. W późniejszym badaniu Brown i wsp. opisali przy użyciu skali DAS siłę działania leku Xeomin, stanowiąca ok. 50\% siły działania zwiotczającego preparatu Botox [25]. W kolejnym badaniu porównawczym z zastosowaniem DAS wykazano, że Dysport wymaga większych dawek $\left(\mathrm{ED}_{50}=41,272 \mathrm{U} / \mathrm{kg}\right.$, $p<0,001)$ do wywołania tego samego efektu, jaki obserwowano po podaniu preparatu Botox $\left(\mathrm{ED}_{50}\right.$ $=11,972 \mathrm{U} / \mathrm{kg}$ ) [26]. Nie jest to poglacd powszechnie akceptowany. Przeciwstawne dane na temat aktywności preparatu Dysport opisał Pickett [27]. Na marginesie należy zaznaczyć, że zarówno Roger Aoki, jak i Andy Pickett są badaczami związanymi kontraktowo z koncernami farmaceutycznymi produkującymi BTX-A (odpowiednio Allergan i Ipsen), co, oczywiście, nie jest kwestionowaniem rzetelności opublikowanych badań.

Ze względu na działanie przeciwbólowe BTX-A przeprowadzono porównanie efektywności Dysportu i Botoksu w osłabianiu bólu indukowanego karragenanem u szczurów (ból indukowany zapaleniem). Badanie wykazało zbliżone wartości $\mathrm{ED}_{50}$ dla preparatów Dysport i Botox (22: $28 \mathrm{U} / \mathrm{kg}$ ) [28].

Preparaty zawierające BTX-A podaje się w celu uzyskania miejscowego efektu - istotne jest zatem minimalizowanie ogólnoustrojowych działań niepożądanych. Podstawowym parametrem jest oznaczenie 
$\mathrm{LD}_{50}$ dla poszczególnych leków. Ocena bezpieczeństwa Botoksu i Xeominu podanych domięśniowo wykazała zbliżoną wartość dla obu preparatów $\left(\mathrm{LD}_{50}=101,7\right.$ : 103,0 U/kg) [29]. W badaniach na myszach po podaniu dootrzewnowym wykazano podobne wartości $\mathrm{LD}_{50}$ dla oczyszczonej BTX-A 150 i kompleksu BTX-A 900 (odpowiednio 0,42 i 0,43 ng/kg) [30]. Ocena porównawcza preparatów Dysport i Botox umożliwiła opisanie proporcji wartości $\operatorname{LD}_{50}: 1,92 \mathrm{j}$. Dyspor$\mathrm{tu}=1,0 \mathrm{j}$. Botoksu [31]. Ryzyko działań niepożądanych systemowych określa współczynnik (margines) terapeutyczny, którego miarą jest proporcja $\mathrm{LD}_{50} / \mathrm{ED}_{50}$. Im jest on większy (większa różnica między dawką efektywną i toksyczną), tym terapia jest bezpieczniejsza. Im mniejszy margines bezpieczeństwa, tym częstsze występowanie efektów niepożądanych w praktyce klinicznej. Współczynnik terapeutyczny był istotnie większy dla Botoksu niż dla Dysportu $(15,1 / 6,1)$ [31], a wg innych autorów wynosił 10,371 dla Botoksu i 5,970 dla Dysportu $(p<0,02)[23]$. Kalkulacja własna $\mathrm{LD}_{50} / \mathrm{ED}_{50}$ na podstawie danych $\mathrm{z}$ innych prac wskazuje na porównywany profil leku Xeomin z preparatem Botox.

\section{Dyfuzja/migracja}

Efekt miejscowy w porównaniu z efektem w dalszym mięśniu w obrębie tego samego rejonu lub kończyny jest kolejnym parametrem, którego znajomość jest konieczna do bezpiecznego podania BTX-A. Określa go współczynnik dyfuzji (margines dyfuzji) szacowany na podstawie proporcji dawki progowej atrofii (threshold dose - TD) (dawki toksyny podanej we wlewie, która powoduje zanik mięśnia czworogłowego) do $\mathrm{ED}_{50}$. Współczynnik dyfuzji dla Botoksu wynosił 6,8 i był znacząco większy niż dla Dysportu $(1,5)$. Wynik ten wskazuje na wąski zakres dawek preparatu Dysport (między dawkami terapeutycznymi i toksycznymi), ryzyko niepożądanych efektów obwodowych i przypuszczalnie mniejszą jego siłę działania, ze względu na szybką migrację preparatu poza miejsce podania. Na podstawie krzywej dawka/efekt autorzy badania sugerują, że zastosowanie preparatu Botox tylko w maksymalnej dawce terapeutycznej lub większej może zapoczątkować dyfuzję leku poza miejsce wstrzyknięcia [32]. Ocenę przemieszczania, dyfuzji preparatów zawierających BTX-A poza miejsce podania oceniano na zwierzętach przy użyciu testu bazującego na ekspresji N-CAM (neural cell adhesion molecule) w mięśniach lub radioaktywnym znakowaniu BTX-A lub metabolitów toksyny. N-CAM jest błonową glikoproteiną, która akumuluje się po odner- wieniu i nie jest obecna w warunkach fizjologicznych. Botox, Dysport i Xeomin podano myszom do mięśnia piszczelowego łap tylnych w proporcjach $1: 4: 1$. Ocena immunohistologiczna i analiza ekspresji N-CAM za pomocą immunoblottingu wykazała zbliżony stopień dyfuzji Botoksu oraz Xeominu i nieco większy Dysportu [14]. Dwudziestoczterogodzinna obserwacja penetracji znakowanych materiałem radioaktywnym preparatów Botox i Xeomin z mięśnia brzuchatego łydki szczura potwierdziła mniejsze rozprzestrzenianie preparatu Botox [33]. Dane na temat penetracji preparatu Dysport wskazują na jego szybsze i łatwiejsze przenikanie poza miejsce podania [31], co może wynikać z niejednorodnej budowy tego leku. Odmienną interpretację na temat migracji preparatu Dysport przedstawił Pickett. Uważa on, że lepsza migracja potwierdza większą siłę działania leku [27].

\section{Porównanie siły działania jednostek poszczególnych preparatów we wskazaniach klinicznych}

Od wielu lat toczy się dyskusja dotycząca różnic w sile działania poszczególnych preparatów toksyny botulinowej. Ma ona znaczenie nie tylko praktyczne (jak przeliczać dawki przy przechodzeniu z jednego preparatu na drugi, jak uniknąć związanych z tym działań niepożądanych), ale także ekonomiczne (ekwiwalencja cenowa ampułek). Obecnie, w związku z pojawieniem się nowej postaci BTX-A (Xeomin firmy Merz), liczba prac na ten temat jeszcze się zwiększyła.

Jakie czynniki mogą determinować różnice w sile działania poszczególnych preparatów? Na pewno należą do nich: proces technologii produkcji leku, zawartość białek stabilizujących, sposób rozcieńczania leku, technika wstrzykiwania i immunooporność [34]. W opublikowanych pracach porównujących siłę jednostek poszczególnych preparatów istnieje wiele punktów budzących wątpliwości. Niemal wszystkie prace dokonywały pewnego wstępnego założenia równoważności dawek, potem ta hipoteza była weryfikowana. Różne też były modele kliniczne prac, w których dokonywano porównań siły jednostek: dystonia szyjna, kurcz powiek, połowiczy kurcz twarzy, nadpotliwość, zmarszczki na czole, elektrofizjologiczna odpowiedź z mięśnia prostownika krótkiego palców. Prace różniły się także schematem podania leku (różne punkty i liczba wstrzyknięć), co - niestety - również utrudnia porównywanie wyników. W praktyce klinicznej może to wyglądać jeszcze inaczej niż w badaniach klinicznych. Przykładem 
może być kurcz powiek i zupełnie odmienne miejsca podania leku preferowane przez różne firmy (bardziej dystalnie, w części zewnętrznej mięśnia okrężnego oka w przypadku preparatu Dysport oraz blisko brzegu powiek, przedtarczkowo w przypadku preparatu Botox) czy preferowana liczba punktów wstrzyknięć. Podanie leku o potencjalnie większej dyfuzji proksymalnie (za taki preparat uchodzi Dysport) pozwala zmniejszyć jego dawkę i uzyskać ten sam efekt przy przeliczniku niekorzystnym dla preparatu Botox. Podanie natomiast tej samej dawki w tych samych punktach może z kolei dać niekorzystny efekt w postaci większej liczby działań niepożądanych w przypadku preparatu Dysport. Dodatkowo, różnica może dotyczyć optymalnego dla danego preparatu rozcieńczenia, liczby punktów wstrzyknięć, wielkości igły i strzykawki. Szczególnie rozcieńczenie może być czynnikiem istotnie zmieniającym skuteczność leku (im większe, tym lepsza), co udowodnili w niedawno opublikowanym badaniu Gracies i wsp. [35] . W zasadzie wydaje się, że nie powinno być problemów z określeniem siły działania poszczególnych preparatów, ponieważ definicja jednostki jest taka sama (patrz wyżej). Problem jednak w tym, że każda firma posługuje się nieco odmienną metodyką, co m.in. spowodowało, że w ampułce preparatów Botox i Xeomin mamy 100 j. toksyny, a w ampułce preparatu Dysport aż $500 \mathrm{j}$. Brak jednego testu wystandaryzowanego międzynarodowo utrudnia bezpośrednie porównanie jednostek zawartych w poszczególnych preparatach. Dodatkową trudność sprawia różnica w aktywności substancji w poszczególnych ampułkach czy seriach, co jest jednak dopuszczalne w przypadku preparatów biologicznych.

\section{Porównanie Botoksu z Dysportem}

W pierwszych pracach z lat 90. porównywano siłę działania tych dwóch preparatów w najczęstszych wskazaniach klinicznych (dystonie ogniskowe, połowiczy kurcz twarzy). Durif i wsp. w kurczu powiek i połowiczym kurczu twarzy uzyskali odpowiednio 50 i 62 -procentową skuteczność przy takim samym czasie działania obu leków i równoważności dawek: Botox : Dysport $=1: 5,3-6,0 \mathrm{j}$. [36]. Z kolei Nussgens i Roggenkamper w kurczu powiek wyliczyli równoważność na $1: 4$, notując jednocześnie statystycznie znamiennie więcej objawów niepożądanych (głównie opadanie powieki) w grupie chorych leczonych preparatem Dysport [37]. Podobny przelicznik $1: 4$ potwierdzili (taka była hipoteza robocza) autorzy portugalscy Sampaio i wsp. w przeprowadzonym metodą pojedynczej ślepej próby badaniu u 91 chorych z kurczem powiek i połowiczym kurczem twarzy [38]. $\mathrm{W}$ innym rodzaju dystonii ogniskowej - kręczu karku Odergren i wsp. w badaniu przeprowadzonym metodą podwójnie ślepej próby, posługując się skalą oceny wg Tsui, uzyskali po 4 tyg. od podania leku współczynnik $1: 3$ między preparatami Botox i Dysport, przy podobnym czasie działania i objawach niepożądanych [39].

Nowsze badania pochodzące $z$ ostatniej dekady dotyczyły również dystonii szyjnej i kurczu powiek oraz połowiczego kurczu twarzy. Bihari w badaniu przeprowadzonym w układzie naprzemiennym (cross-over) uzyskała współczynniki w przedziale $1: 4$ do $1: 5$ [40], a Ranoux i wsp. u chorych z dystonią szyjną (badanie w układzie naprzemiennym, prowadzone metodą podwójnie ślepej próby) uzyskali przeliczniki $1: 3$ i $1: 4$ (dla poprawy ruchowej i bólu). Zanotowali jednak więcej działań niepożądanych, szczególnie dysfagii, w grupie leczonej preparatem Dysport (3\% Botox, 17,3\% Dysport). Trudno jednak w tej pracy znaleźć ilości bezwzględne (dawki) podanych preparatów [41]. W systematycznym przeglądzie [42] jedynie 3 prace uzyskały wysokie oceny jakości $[37,38,41]$ i przelicznik dawek mieścił się $\mathrm{w}$ nich w granicach $1: 3-1: 4$. Jak wspomniano wcześniej, różne podejście metodologiczne utrudnia porównywanie poszczególnych badań. Dobrym przykładem są tu badania Ranoux i wsp. [41] oraz Odergrena i wsp. [39], gdzie w przypadku preparatu Botox stosowano dawki odpowiednio 100 i $150 \mathrm{j}$. W badaniach klinicznych obu preparatów z wykorzystaniem placebo (Botox -7 badań, Dysport - 5 badań) średnie dawki leków w dystonii szyjnej wynosiły odpowiednio 150 i 900 j. Trudno zatem również dokonywać porównań pośrednich między tymi lekami [42]. Porównania skuteczności preparatów dokonywano także w innych modelach klinicznych (nadpotliwość, zmarszczki na czole). W badaniach tych wzięło udział łącznie 48 chorych. Uzyskane przeliczniki to $1: 4,1: 2,5,1: 3$, ale grupy chorych nie były zbyt liczne [43-45]. Pracą, która porównywała skuteczność obu preparatów w naturalnych warunkach klinicznych (retrospektywną), była publikacja Marchetti i wsp., oceniająca skuteczność obu leków przy zamianie preparatów (z Botoksu na Dysport, z Dysportu na Botox) u chorych z dystonią szyjną i kurczem powiek. Do badania włączono 114 chorych w 6 ośrodkach w Europie. Zanotowano zaskakująco duży rozrzut dawek równoważnych od 1 : 11 do $1: 2$ (Botox : Dysport). Jedynie $31 \%$ chorych mieściło się $\mathrm{w}$ przeliczniku $1: 5-1: 6,30 \%$ w przedziale $1: 5-1: 4$ oraz kolej- 
ne $21 \%$ w przedziale $1: 4-1: 3$. Średni przelicznik w obu wskazaniach i obu przejściach z leku na lek wyniósł $1: 4,48$ [46].

Zupełnie inne wyniki osiągnięto w modelach eksperymentalnych. W preparacie mysiej przepony stymulowanej elektrycznie, preparaty Botox i Dysport wykazywały tę samą aktywność jednostki leku. W badaniu na zdrowych ochotnikach, którym wstrzyknięto do mięśnia prostownika krótkiego stopy (EDB) $5 \mathrm{j}$. każdego z preparatów w tej samej objętości, uzyskano identyczne krzywe spadku amplitudy po stymulacji elektrycznej. Czas do wystąienia działania leku i czas jego utrzymywania się były również identyczne [47]. W $2008 \mathrm{r}$. Wolfarth i wsp. opublikowali dane $\mathrm{z}$ badania 79 ochotników, posługując się wspomnianą powyżej metodą elektroneurograficzną (test EDB). Było to badanie $\mathrm{z}$ randomizacją, prowadzone metodą podwójnie ślepej próby, które trwało 12 tyg. Podawano do jednej stopy Dysport (od 2,5 do 20 j.), a do drugiej Botox (od 1,25 do $10 \mathrm{j}$.) w różnych rozcieńczeniach. Zwiększenie dawki i rozcieńczenia leku w przypadku obu preparatów powodowało większe osłabienie mięśnia (większy spadek amplitudy po stymulacji), większe rozcieńczenie powodowało także większą dyfuzję do sąsiednich mięśni. Analiza statystyczna dała zaskakujące wyniki. Równoważność jednostek określono w proporcjach Botox : Dysport jako $1: 1,57$. Autorzy wnioskują, że mieści się to $\mathrm{w}$ granicach błędu $\mathrm{z}$ innych badań w modelach klinicznych, sugerujących przelicznik $1: 3$ [48]. Ci sami autorzy w przeglądzie badań z 2009 r. porównujących oba leki piszą jednak, że ekstrapolacja wyników z modeli doświadczalnych do badań klinicznych powinna być dokonywana ostrożnie [49].

W najnowszym badaniu opublikowanym w $2009 \mathrm{r}$. porównano oba preparaty, podając je śródskórnie na brzuchu i oceniając pole obniżonego wydzielania potu. Stosowano 3 różne rozcieńczenia leku. W przypadku obu leków stwierdzono efekt działania zwiększający się liniowo w zakresie dawki i podanej objętości. Jednakże równoważniki dawek były zaskakująco odmienne od dotychczas publikowanych, średnio $1: 2$ (Botox : Dysport). Nie stwierdzono także różnicy w dyfuzji [50]. Trzeba jednak stwierdzić, że model ten może nie być przydatny w przypadku wstrzykiwania leku do mięśni. Gruczoły potowe reagują inaczej niż mięśnie - obszar działania leku jest mniejszy (konieczne wstrzyknięcia co 1-2 cm), a czas reinerwacji dłuższy (poprawa utrzymuje się nawet 6 miesięcy i dłużej).

Jeżeli przelicznik dawek byłby bliski $1: 1$ lub $1: 2$, to można zadać sobie pytanie, dlaczego w warunkach klinicznych ta 4-5-krotnie większa siła działania preparatu Dysport nie jest widoczna. W metaanalizie badań porównującej oba preparaty w leczeniu dystonii szyjnej czas działania Dysportu był nawet krótszy niż Botoksu, natomiast liczba przypadków dysfagii większa. Czy świadczy to o większej sile działania Dysportu czy o jego większej dyfuzji z miejsca podania? Na te pytania trudno dziś jednoznacznie odpowiedzieć [51].

\section{Porównanie Botoksu z Xeominem}

Oba leki porównano w dwóch badaniach (dystonia szyjna, kurcz powiek), skonstruowanych jako tzw. noninferiority studies, zakładając wstępnie biorównoważność obu preparatów. Badaniem w dystonii szyjnej objęto aż 463 chorych poddanych 16-tygodniowej ocenie - pokazało ono porównywalny (brak statystycznie znamiennych różnic) efekt działania obu leków w zakresie poprawy klinicznej, czasu działania i objawów niepożądanych [52]. Podobne wyniki uzyskano 3 tyg. po jednorazowym podaniu obu leków w kurczu powiek [53]. Również w badaniach eksperymentalnych - na zdrowych ochotnikach w teście mięśnia prostownika krótkiego palców - w dwóch badaniach nie uzyskano istotnych różnic między preparatami [54].

Jednakże w modelu mysim, przeprowadzając ocenę za pomocą procedury standardowo oceniającej sitę działania preparatu Botox, uzyskano wyniki sugerujące, że siła działania jednej fiolki preparatu Xeomin wynosi ok. $70 \%$ siły preparatu Botox. Jak zwykle w takich badaniach wymagają one powtórzenia i ostrożności przy przenoszeniu na model kliniczny [55].

\section{Porównanie preparatów toksyny botulinowej typu A pod względem immunogenności}

Problem wtórnej oporności na BTX-A spowodowanej immunizacją i obecnością swoistych przeciwciał pojawił się z chwilą, gdy lek wprowadzono do leczenia dystonii szyjnej, co wiązało się ze stosowaniem większych dawek niż w kurczu powiek czy połowiczym kurczu twarzy. Testy laboratoryjne stosowane do wykrywania przeciwciał przeciwko BTX-A różnią się czułością i swoistością. Testy immunologiczne (ELISA, immunoprecypitacja, Western blot) charakteryzują się dużą czułością, ale małą swoistością (tzn., że wykazują także obecność przeciwciał nieneutralizujących) [56]. Testy biologiczne (np. mouse protection assay, mouse diaphragm assay) cechuje natomiast większa swoistość i lepsza ko- 
relacja z danymi klinicznymi, ale są mniej czułe. Wynik mouse protection assay jest dodatni jedynie u ok. 30-50\% pacjentów niereagujących na lek [57], ale stanowi on „złoty standard” w badaniach klinicznych. W pracach opublikowanych w latach 90 . ubiegłego wieku oceniano, że wtórna oporność dotyczy nawet $10 \%$ pacjentów leczonych z powodu dystonii szyjnej. Czynnikami wystąpienia ryzyka były większe dawki podawane jednorazowo, większa dawka skumulowana, krótszy czas pomiędzy kolejnymi sesjami oraz stosowanie dawek uzupełniających [58-62]. W grudniu 1997 r. na rynek wprowadzono nową postać preparatu Botox. W wersji wcześniejszej lek zawierał $25 \mathrm{ng}$ białka/100 j. W wersji nowej, stosowanej do dzisiaj, jest to $5 \mathrm{ng} / 100 \mathrm{j}$. [63]. Pierwsze doniesienia wykazały, że terapia z zastosowaniem nowej postaci Botoksu spowodowała - przy niezmienionej skuteczności - sześciokrotne zmniejszenie ryzyka wystąpienia immunizacji [64]. Nowe doniesienia potwierdzają, że długotrwałe podawanie obecnej formuły Botoksu wiąże się z bardzo małym ryzykiem wystąpienia immunizacji i wtórnej oporności [65]. W grupie 326 chorych z dystonią szyjną, którym wielokrotnie podawano lek (od 1 do 15, średnio 9 wstrzyknięć; 187,0 \pm 76,5 j. podczas sesji), tylko u czworga $(1,2 \%)$ stwierdzono obecność przeciwciał (mouse protection assay). Nie zaobserwowano przy tym prostej zależności pomiędzy obecnością przeciwciał i kliniczną odpowiedzią na podanie leku. Jeden z pacjentów pomimo utrzymywania się przeciwciał reagował na kolejne wstrzyknięcia. Z kolei u dwóch innych pacjentów obecność przeciwciał stwierdzono jednorazowo i kolejne oznaczenia nie wykazywały ich obecności. Podczas następnych sesji chorzy ci zostali uznani za niereagujących na lek, ale testy kliniczne (podanie leku do mięśnia czołowego lub mięśnia marszczącego brwi) nie potwierdziły oporności. Analiza skumulowanych danych z 3 badań oceniających skuteczność Botoksu w terapii poudarowej spastyczności kończyn również wykazała małą immunogenność tego preparatu [66]. Spośród 191 pacjentów, którym lek podano 1-4 razy (dawka 100-400 j., średnio 241 j.), tylko u jednego $(0,5 \%)$ wykryto obecność przeciwciał. Nie było przy tym jasne, czy przeciwciała pojawiły się dopiero po rozpoczęciu leczenia. Duża wtórna oporność przy stosowaniu pierwszej wersji preparatu i wprowadzenie na rynek jego nowej formuły miały wpływ na to, że więcej danych dotyczaçch immunogenności dostępnych jest na temat Botoksu niż Dysportu. Ostatnio opublikowano pracę porównującą skuteczność i częstość występowania przeciwciał neutralizujących u pacjentów z dystonią szyjną leczonych przewlekle Botoksem (średnia dawka
$145 \pm 44$ j.) lub Dysportem (389 \pm 144 j.). Przy porównywalnej skuteczności i profilu działań niepożądanych obu leków, w obu przypadkach zanotowano częstość występowania przeciwciał ponizej 2\% [67].

Dostępne obecnie dane pozwalają stwierdzić, że terapia przy użyciu Botoksu i Dysportu - prowadzona nawet przez wiele lat - obciążona jest małym ryzykiem wystąpienia immunizacji i spowodowanej nią wtórnej oporności. Xeomin jest obecny na rynku zbyt krótko, by można go porównywać z pozostałymi preparatami typu A. Stosowanie BTX typu B wiąze się ze znacznie większym zagrożeniem immunizacją [68]. Po 42-tygodniowej terapii obecność przeciwciał neutralizujących stwierdzono u 34,4\% leczonych [69]. Nie zostało do końca wyjaśnione, czy wcześniejsze stosowanie BTX-A powoduje szybsze rozwinięcie się oporności na BTX-B, czego nie można wykluczyć, biorąc pod uwagę daleko idącą homologię cząsteczek obu serotypów.

\section{Porównanie preparatów toksyny botulinowej w leczeniu dystonii ogniskowych}

\section{Dystonia szyjna (kręcz karku)}

Toksyna botulinowa typu A jest obecnie powszechnie uznana za najskuteczniejszy, a także bezpieczny lek w terapii dystonii szyjnej i rekomendowana jako leczenie z wyboru przez ekspertów zarówno amerykańskich, jak i europejskich. Opublikowany w 2008 r. raport ekspertów Amerykańskiej Akademii Neurologii, na podstawie analizy 7 badań klasy I (4 badania typu A i 3 badania typu B) na łącznym materiale 584 chorych na dystonię szyjną, stwierdza, że terapia BTX-A spełnia kryteria poziomu rekomendacji A. Dla porównania, leczenie innymi lekami, np. podawanym doustnie triheksyfenidylem, zostało ocenione $\mathrm{w}$ tym raporcie na poziomie rekomendacji B [70]. Podobna ocena została przedstawiona w 2005 r. na podstawie analizy 13 publikacji w bazie Cochrane [71]. Porównanie skuteczności i bezpieczeństwa trzech preparatów BTX-A (Botox, Dysport, Xeomin) zarejestrowanych w Polsce do leczenia dystonii szyjnej było dotychczas przedmiotem tylko kilku prac poglądowych lub metaanaliz porównujących tylko Botox i Dysport, które nie wykazały istotnych różnic między tymi preparatami $[4,42]$. W dostępnym piśmiennictwie znaleziono tylko 3 publikacje poświęcone bezpośredniemu porównaniu (head-to-head) skuteczności i profilu objawów niepożądanych Botoksu i Dyspor- 
tu [39-41] oraz tylko jedno badanie porównujące Botox z Xeominem [52]. Wszystkie te próby kliniczne miały charakter badań z randomizacją z zastosowaniem ustalonej proporcji dawek i kwalifikowano do nich chorych wcześniej skutecznie leczonych preparatem Botox. Porównując działanie Dysportu i Botoksu, stosowano współczynnik przeliczenia dawek od $3: 1$ do $5: 1$, a Xeominu i Botoksu w stosunku dawek 1 : 1. Wyniki poszczególnych badań różniły się. Porównując Botox i Dysport, w jednym badaniu stwierdzono lepszą skuteczność Botoksu [40], w drugim Dysportu [41], a w trzecim podobną skuteczność obu preparatów [39]. W badaniu porównującym Botox z Xeominem nie wykazano różnic między preparatami w dystonii szyjnej [52] (tab. 2.).

Dokładniejsza analiza tych badań wskazuje, że w każdym z nich stosowano nieco odmienną procedurę badania i metodologię oceny skuteczności działania, co w praktyce uniemożliwia ich wartościową analizę porównawczą. W badaniu Bihari [40] 12 chorych było leczonych początkowo Dysportem, a następnie Botoksem w stosunku dawek $5: 1$ lub $4: 1$. U chorych leczonych Botoksem zarejestrowano większą redukcję nasilenia objawów klinicznych $(p=0,012)$, dłużej trwającą poprawę kliniczna ( $p=0,014)$ i rzadziej występujące objawy niepożądane w porównaniu z leczeniem Dysportem. Osłabienie mięśni karku, najczęstszy z objawów niepożądanych, wystąpił jedynie podczas leczenia Dys- portem. Badanie Ranoux i wsp. [41] prowadzone było w układzie naprzemiennym z porównaniem Dysportu i Botoksu w przy użyciu przeliczników dawek 3 : 1 i 4 : 1 w 3 grupach badanych, w 3 kolejnych sesjach terapeutycznych. Do badania włączono chorych uprzednio leczonych co najmniej dwukrotnie Botoksem, u których uzyskano poprawę. Każdy chory poddany był 3 cyklom terapii w różnej kolejności. U chorych leczonych Dysportem stwierdzano większą redukcję objawów ruchowych ocenianych w skali Tsui niż u chorych leczonych Botoksem. Wynik leczenia zależał od stosowanych dawek. W przypadku stosowania dawek Dysportu do Botoksu jak 1 : 3 średnie zmniejszenie liczby punktów w skali Tsui po leczeniu Botoksem wynosiło 3,2 pkt, a Dysportem 4,3 pkt ( $p=0,02)$. Przy dawkowaniu jak 1 : 4 średnie zmniejszenie punktacji po leczeniu Dysportem było jeszcze większe (4,9 pkt, $p=0,01)$. Podobnie lepsze wyniki zależne od stosunku dawek osiągnięto również w ocenie skali bólu. Także średni czas poprawy klinicznej był dłuższy u leczonych Dysportem niż Botoksem: o 7 dni przy stosunku dawek $1: 3$ $(p=0,58)$ lub o 25 dni przy stosunku dawek $1: 4$ $(p=0,02)$. U chorych otrzymujących Dysport stwierdzono jednak dwukrotnie częstsze występowanie objawów niepożądanych (36\% w porównaniu z 17,6\%) niezależnie od stosunku dawek. Szczególnie często, bo aż pięciokrotnie częściej, obserwowano zaburzenia połykania u chorych leczonych Dysportem $(15,6 \%$ i 17,3\%

Tabela 2. Porównanie preparatów toksyny botulinowej A w leczeniu dystonii szyjnej

Table 2. The comparison of botulinum toxin type A preparations in the treatment of cervical dystonia

\begin{tabular}{|c|c|c|c|c|c|c|}
\hline Badanie/rok & $\begin{array}{l}\text { Badane preparaty, } \\
\text { stosunek dawek }\end{array}$ & $\begin{array}{l}\text { Liczba } \\
\text { chorych }\end{array}$ & $\begin{array}{l}\text { Czas poprawy } \\
\text { (dni) }\end{array}$ & $\begin{array}{l}\text { Metoda oceny } \\
\text { skuteczności }\end{array}$ & $\begin{array}{c}\text { Poprawa kliniczna } \\
\text { Botox/Dysport lub Xeomin }\end{array}$ & $\begin{array}{l}\text { Objawy niepożq̨dane } \\
\text { Botox/Dysport lub Xeomin }\end{array}$ \\
\hline $\begin{array}{l}\text { Odergren } \\
\text { i wsp., } 1998 \\
{[39]}\end{array}$ & $\begin{array}{c}\text { Botox/Dysport } \\
1: 3 \\
152 \text { j. }(7 \mathrm{j} \cdot-420 \mathrm{j} .) / \\
477 \text { j. }(240 \mathrm{j} .-720 \mathrm{j} .)\end{array}$ & 73 & $\begin{array}{c}80,7 \text { vs } 83,9 \\
p=0,85\end{array}$ & Tsui & $\begin{array}{l}5,0 \text { vs } 4,8 \\
p=0,66\end{array}$ & $\begin{array}{c}69 \% \text { vs } 58 \% \\
p=0,35\end{array}$ \\
\hline $\begin{array}{l}\text { Ranoux } \\
\text { i wsp., } 2002 \\
{[41]}\end{array}$ & $\begin{array}{c}\text { Botox/Dysport } \\
1: 3 \\
104 \text { j. }(70 \text { j. }-180 \text { j. }) / \\
313 \text { j. }(210 \text { j. }-540 \text { j. }) \\
1: 4 \\
104 \text { j. }(70 \text { j. }-180 \text { j. }) / \\
417 \text { j. }(280 \text { j. }-720 \text { j. })\end{array}$ & 51 & $\begin{array}{c}1: 3 \\
89,3 \text { vs } 96,9 \\
p=0,58 \\
1: 4 \\
89,3 \text { vs } 114 \\
p=0,02\end{array}$ & $\begin{array}{c}\text { Tsui } \\
\text { TWSTRS }\end{array}$ & $\begin{array}{c}1: 3 \\
\text { Tsui: } 3,2 v s 4,3, p=0,02 \\
1: 4 \\
\text { Tsui: } 3,2 \text { vs } 4,9, p=0,01 \\
\text { TWSTRS - ból } \\
1: 3 p=0,04 \\
1: 4 p=0,02\end{array}$ & $\begin{array}{c}1: 3 \\
3 \% \text { vs } 15,6 \% \\
1: 4 \\
3 \% \text { vs } 17,3 \%\end{array}$ \\
\hline $\begin{array}{l}\text { Bihari, } 2005 \\
{[40]}\end{array}$ & $\begin{array}{c}\text { Botox/Dysport } \\
1: 4-1: 5\end{array}$ & 12 & $\begin{array}{l}64,3 \text { vs } 44,6 \\
p=0,014\end{array}$ & TWSTRS & $\begin{array}{c}\text { skuteczniejszy Botox } \\
\quad p=0,012\end{array}$ & $\begin{array}{l}\text { osłabienie mięśni karku tylko } \\
\text { w grupie leczonej Dysportem }\end{array}$ \\
\hline $\begin{array}{l}\text { Benecke } \\
\text { i wsp., } 2005 \\
{[52]}\end{array}$ & $\begin{array}{c}\text { Botox/Xeomin } \\
1: 1 \\
138( \pm 46,8) / 140( \pm 51,4) \\
\text { zakres: } 70-300\end{array}$ & 420 & $\begin{array}{c}94,3 \text { vs } 95,9 \\
p=0,91\end{array}$ & $\begin{array}{l}\text { TWSTRS, } \\
\text { VAS, GAS }\end{array}$ & $\begin{array}{c}\text { TWSTRS } \\
-6,4 v s-6,6 \text { pkt, } p=\text { n.s. } \\
\text { VAS } \\
-11,8 v s-8,8, p=0,2\end{array}$ & $28,1 \%$ vs $24,1 \%, p=$ n.s. \\
\hline
\end{tabular}

TWSTRS - Toronto Western Spasmodic Torticollis Rating Scale, VAS - Visual Analogue Scale, GAS - Global Assessment Scale, n.s. - nieistotne statystycznie 
w porównaniu z 3\%). Do badania Odergrena i wsp. [39] zakwalifikowano 73 chorych poprzednio wielokrotnie (minimum czterokrotnie) leczonych BTX-A, u których uzyskano poprawę. Było to badanie z randomizacją porównujące działanie Botoksu i Dysportu w stosunku dawek $1: 3$, w dwóch równolegle leczonych grupach. Chorzy zakwalifikowani do grupy leczonej Botoksem mieli na początku nieco bardziej nasilone objawy w skali Tsui (średnio 8,5 pkt) niż osoby leczone Dysportem (średnio 7,4 pkt) i dłuższy czas choroby (132 w porównaniu ze 103 miesiącami), co mogło mieć wpływ na wynik oceny. Średnia dawka Dysportu wynosiła 477 j., a Botoksu 152 j. Po 2 tyg. od wstrzyknięcia u $85 \%$ chorych leczonych Dysportem i $83 \%$ chorych leczonych Botoksem stwierdzono poprawę kliniczną w tym samym nasileniu, ze średnią redukcją punktacji w skali Tsui wynoszącą w obu grupach ok. $30 \%$. Po 4 tyg. podobnego odsetka chorych w każdej z grup utrzymywała się nadal poprawa, ale redukcja objawów dystonii powyżej 50\% częściej występowała w grupie leczonej Dysportem niż Botoksem (średnia w skali Tsui po 4 tyg. wynosiła odpowiednio 3,8 i 4,7 pkt). Nie wykazano różnicy w czasie działania obu preparatów ani w częstości występowania objawów niepożądanych, które obserwowano u $58 \%$ chorych leczonych Dysportem i 69\% chorych leczonych Botoksem. Wśród objawów niepożądanych najczęstsza była dysfagia. Nie wykazano znamiennej statystycznie różnicy między preparatami w ocenie skuteczności i bezpieczeństwa leczenia ( $p=0,32$ ). Sampaio i wsp. przeprowadzili metaanalizę dwóch powyższych badań (Odergrena i wsp. oraz Rannouksa i wsp.), stwierdzając, że redukcja nasilenia objawów w skali Tsui przy stosunku dawek $3: 1$ była u chorych leczonych Botoksem mniejsza o prawie 0,5 punktu i trwała krócej o 4 dni niż u leczonych Dysportem, ale różnica nie była znamienna statystycznie. Znamienność statystyczną różnic na korzyść Dysportu stwierdzono jednak przy stosunku dawek $4: 1$, zarówno w odniesieniu do redukcji nasilenia objawów w skali $(p=0,004)$, jak i czasu poprawy $(p=0,03)$. W tym stosunku dawek liczba objawów niepożądanych po Dysporcie była jednak znacząco większa niż po Botoksie $(p=0,03)$. Oceniając wyniki powyższej metaanalizy, należy jednak zwrócić uwagę, że dawki Botoksu stosowane w badaniu Odergrena i wsp. były znacząco większe niż w badaniu Rannouksa i wsp. (150 j. w porównaniu ze 100 j.) [42]. W obu badaniach stosowano również odmienne protokoły badania: leczenie w układzie równoległym (Odergren i wsp.) lub naprzemiennym (Ranoux i wsp.).

W jedynym opublikowanym dotychczas badaniu oceniającym skuteczność leczenia dystonii szyjnej Botoksem i Xeominem, Benecke i wsp. na materiale 463 chorych wykazali porównywalną skuteczność i bezpieczeństwo obu preparatów w stosunku dawek $1: 1$ [52]. Analizę przeprowadzono ostatecznie u 420 chorych (209 chorych leczonych Xeominem i 205 leczonych Botoksem) obserwowanych do 16 tyg. po wstrzyknięciu. Po 28 dniach od wstrzyknięcia leku poprawę w skali TWSTRS w zakresie nasilenia ruchów i bólu stwierdzono zarówno u chorych leczonych Botoksem, jak i Xeominem. Średnia redukcja nasilenia ruchów wynosiła dla obu preparatów odpowiednio 6,4 i 6,6 pkt $(p>0,05)$, a bólu: $-0,6$ i $-0,4$ pkt $(p=0,4)$. Obie leczone grupy nie różniły się również czasem poprawy (94,3 w porównaniu z 95,9 dnia) ani liczbą objawów niepożądanych (24\% w porównaniu z 28\%). Najczęściej obserwowanym objawem niepożądanym była dysfagia, która wystąpiła u 8,2\% chorych leczonych Botoksem i u 10,8\% chorych leczonych Xeominem. Oprócz badań porównawczych opublikowano dotychczas ponad 80 badań oceniających skuteczność i bezpieczeństwo poszczególnych preparatów BTX-A w leczeniu dystonii szyjnej, ale tylko niewielka część tych badań spełnia odpowiednie wymogi metodologiczne, np. badań klasy A. W wymienionej wcześniej metaanalizie bazy Biblioteki Cochrane'a [71] znalazło się tylko 13 badań z randomizacją i z grupą kontrolną otrzymującą placebo, z zastosowaniem Dysportu lub Botoksu. Jednym z elementów przeprowadzonej analizy było pośrednie porównanie skuteczności i bezpieczeństwa dwóch powyższych preparatów. Do analizy włączono wszystkie spełniające powyższe kryteria prace, które zostały opublikowane w latach 1977-2004 . Były to raporty z obserwacji trwających 6-16 tyg., obejmujące 361 chorych leczonych Botoksem (8 badań) i 319 chorych leczonych Dysportem (5 badań). Zarówno dawki, jak i techniki podania znacząco różnity się między poszczególnymi raportami. Ostrzykiwano 2-4 mięśni, w 2-11 punktach na mięsień i pod kontrolą EMG w połowie badań. Średnie dawki Botoksu stosowane w powyższych pracach wynosity $188 \mathrm{j}$. (50-280 j.), a Dysportu - 577 j. (250-1000 j.). Według autorów powyższej analizy oba preparaty toksyny botulinowej mają taką samą skuteczność i bezpieczeństwo stosowania. Zarówno skuteczność, jak i nasilenie objawów niepożądanych zależne były od dawki leków. Wśród najczęstszych objawów niepożądanych stwierdzano osłabienie mięśni szyi, dysfagię, suchość śluzówek ust i gardła oraz zaburzenia brzmienia głosu o typie chrypki i dysfonii.

Porównanie skuteczności i bezpieczeństwa różnych preparatów toksyny botulinowej w leczeniu dystonii szyjnej jest trudne $\mathrm{z}$ wielu powodów. Po pierwsze, zarówno 
wyniki badań na zwierzętach, jak i badań klinicznych nie doprowadziły do jednoznacznego określenia ekwiwalentnej dawki Dysportu i Botoksu (patrz wyżej). Po drugie, przeprowadzone badania były niejednokrotnie nieporównywalne w aspekcie odmiennej metodologii oceny klinicznej i efektu działania, procedur badania oraz materiału.

Najważniejsze różnice to:

1. Różne, często nieporównywalne skale oceny klinicznej chorego (Toronto Western Spasmomodic Torticollis Rating Scale lub skala Tsui).

2. Sztywne protokoły badania narzucające ostrzykiwanie niezmienionymi dawkami w kolejnych sesjach tylko określonej grupy mięśni.

3. Różne typy badań klinicznych (w badaniach z randomizacją i z grupą kontrolną otrzymującą placebo, prowadzonych metodą podwójnie ślepej próby uzyskiwano zawsze gorsze wyniki efektów leczenia BTX-A $\mathrm{w}$ dystonii szyjnej niz w badaniach otwartych). Badania otwarte na 303 chorych z możliwością indywidualnego dostosowywania dawek i miejsc wstrzyknięcia ujawniły aż u $92 \%$ poprawę ruchów i u $93 \%$ redukcję bólu [72], natomiast w badaniach prowadzonych metodą podwójnie ślepej próby zmniejszenie ruchów dystonicznych stwierdzano zaledwie u $70 \%$ chorych [73].

4. Różne badane grupy (różny czas trwania choroby, wcześniejsze leczenie BTX-A lub brak takiego leczenia, różny czas leczenia) [74].

\section{Kurcz powiek (blefarospazm)}

Leczenie kurczu powiek wstrzyknięciami BTX-A jest powszechnie uznawane za najbardziej skuteczną metodę. Co więcej, jest to wskazanie, w którym ta skuteczność wydaje się być największa w porównaniu z innymi postaciami dystonii. W raporcie przygotowanym przez ekspertów Amerykańskiej Akademii Neurologii w 2008 r. BTX-A w leczeniu kurczu powiek osiagnęła jednak poziom rekomendacji B, co związane jest przede wszystkim z brakiem badań klinicznych oceniających skuteczność leku w porównaniu z placebo [70]. Na podstawie przeglądu badań na temat skuteczności i bezpieczeństwa leczenia kurczu powiek porównanie dostępnych preparatów jest niezwykle trudne. Wiąże się to przede wszystkim z brakiem badań klasy I, niewielką liczbą badań klinicznych klasy II, brakiem badań porównawczych typu headto-head. Ponadto, opublikowane badania różnią się między sobą metodyką, która dotyczy m.in.:

1. Różnych skal oceny poprawy: skala poprawy VAS, skala Jankovica (JRS), skala oceny niesprawności (blepharospasm disability index - BSDI).
2. Technik podawania leku (przedtarczkowe lub przedprzegrodowe).

3. Dawek preparatów (brak ustalonego współczynnika konwersji Botoksu na Dysport).

Wydaje się, że na podstawie przeprowadzonych badań można porównać przede wszystkim bezpieczeństwo stosowanych leków [75-79]. Działania niepożądane po podaniu BTX-A w leczeniu kurczu powiek przedstawiono w tab. 3.

Skuteczność leczenia kurczu powiek, polegającą na poprawie o $72 \%$, stwierdzono w badaniu z zastosowaniem Botoksu (w dawce po 25 j. na oko) przeprowadzonym przez Jankovica i Ormana [75]. Zaobserwowano wtedy także, że efekt leczenia pojawia się po 3,7 dnia od wstrzyknięcia i utrzymuje ok. 12,5 tyg. Badanie to przeprowadzono jedynie u 12 chorych i spełnia ono kryteria badania klasy II (podwójnie ślepa próba, grupa kontrolna otrzymująca placebo). Skuteczność i bezpieczeństwo preparatu Dysport w dawce 40, 80 i $120 \mathrm{j}$. Dysportu na oko potwierdzono ostatnio w grupie 92 chorych. Poprawę trwającą ok. 12 tyg. stwierdzono u wszystkich chorych; zauważono jednak, że wielkość dawki wpływała na czas trwania poprawy (do 16 tyg.) i na częstsze występowanie działań niepożądanych (opadanie powieki - $13 \%$ przy dawce $40 \mathrm{j}$. i $58 \%$ przy dawce 120 j.) [79]. Skuteczność BTX-A potwierdzono także w wielu otwartych badaniach klinicznych. Opublikowane ostatnio artykuły przeglądowe Costy i wsp. (2005) [71], Kenneya i Jankovica (2008) [80], Bentivoglio i wsp. (2009) [81] oprócz skuteczności leczenia podkreślają jednak także niedoskonałości metodyczne tych badań.

Istnieją nieliczne badania kliniczne porównujące m.in. skuteczność i bezpieczeństwo obu preparatów $[37,38]$. W badaniach tych potwierdzono podobna skuteczność oraz czas trwania poprawy po podaniu obu leków. Nussgens i wsp. zaobserwowali, że po podaniu Botoksu czas poprawy wynosił 7,98 \pm 3,8 tyg., a po podaniu Dysportu - 8,03 \pm 4,6 tyg. (różnica nieistotna statystycznie). Opadanie powiek występowało natomiast rzadziej po podaniu Botoksu (tab. 3.) [37]. W pracy Sampaio i wsp. zaobserwowano z kolei podobną skuteczność i częstość występowania działań niepożądanych po podaniu obu preparatów. Poprawa po podaniu Dysportu utrzymywała się przez 13,3 \pm 5,9 tyg., a po podaniu Botoksu - 11,2 \pm 5,8 tyg.; uzyskano także podobny stopień poprawy [38]. Podobne wyniki, jak w przypadku porównania Botoksu i Dysportu, otrzymano w próbie klinicznej oceniającej skuteczność nowego preparatu BTX-A o nazwie Xeomin (Xeomin 
Tabela 3. Częstość występowania działań niepożądanych po podaniu toksyny botulinowej A u chorych z kurczem powiek

Table 3. The frequency of adverse events after botulinum toxin type A injections in blepharospasm

\begin{tabular}{|c|c|c|c|c|}
\hline $\begin{array}{l}\text { Badanie } \\
\text { kliniczne }\end{array}$ & $\begin{array}{l}\text { Badana } \\
\text { grupa }\end{array}$ & $\begin{array}{l}\text { Preparat toksyny } \\
\text { botulinowej A oraz dawka }\end{array}$ & Rodzaj badania & Działania niepożq̨dane \\
\hline $\begin{array}{l}\text { Jankovic } \\
\text { i Orman, } \\
1987 \\
{[75]}\end{array}$ & 12 & Botox $25 \mathrm{j}$./oko & $\begin{array}{l}\text { z grupą kontrolną otrzymującą } \\
\text { placebo, prowadzone metodą } \\
\text { podwójnie ślepej próby }\end{array}$ & $\begin{array}{l}\text { widzenie za mgła } 33 \% \text {, łzawienie } 25 \% \text {, } \\
\text { opadanie powiek } 25 \% \text {, wybroczyny w miejscu } \\
\text { podania leku } 33 \% \text {, podwójne widzenie } 8 \% \text {, } \\
\text { czas trwania objawów } 1-3 \text { tyg. }\end{array}$ \\
\hline $\begin{array}{l}\text { Grandas } \\
\text { i wsp., } 1988 \\
{[76]}\end{array}$ & 151 & $\begin{array}{l}\text { 0,4-2,2 ng neurotoksyny A } \\
\text { (nie podano nazwy preparatu) }\end{array}$ & otwarte & $\begin{array}{l}\text { opadanie powiek } 22 \% \text {, diplopia } 11 \% \text {, } \\
\text { osłabienie mięśni twarzy } 5 \% \text {, ektropion } 3 \% \text {, } \\
\text { ogólne osłabienie } 2 \% \text {, dysfagia } 1 \% \text {, dysfonia } 1 \% \text {, } \\
\text { widzenie za mgłą } 1 \%\end{array}$ \\
\hline $\begin{array}{l}\text { Jankovic } \\
\text { i wsp., } 1990 \\
{[77]}\end{array}$ & 70 & Botox $20 \mathrm{j}$./oko & otwarte & $\begin{array}{l}\text { opadanie powiek } 21 \% \text {, podwójne widzenie } 30 \% \text {, } \\
\text { łzawienie } 12 \% \text {, osłabienie miejscowe } 10 \% \text {, } \\
\text { krwiak } 7 \% \text {, obrzęk miejscowy } 4 \% \text {, ból oka } 1 \% \text {, } \\
\text { pieczenie } 1 \% \text {, zaczerwienienie oczu } 1 \% \text {, } \\
\text { nudności } 2 \% \text {, zawroty głowy } 1 \% \text {, bóle głowy } 1 \% \text {, } \\
\text { ból proksymalnych mięśni } 1 \%\end{array}$ \\
\hline $\begin{array}{l}\text { Park } \\
\text { i wsp., } 1993 \text { [78] }\end{array}$ & 11 & $\begin{array}{c}\text { Botox, } \\
\text { średnia dawka: } 22 \mathrm{j} \text {. }\end{array}$ & otwarte & $\begin{array}{l}\text { suchość oka } 27 \% \text {, opadanie powiek } 27 \% \text {, } \\
\text { obrzęk powieki } 1 \% \text {, podwójne widzenie } 1 \%\end{array}$ \\
\hline $\begin{array}{l}\text { Sampaio } \\
\text { i wsp., } 1997 \\
{[38]}\end{array}$ & 42 & $\begin{array}{l}\text { Botox, } 12,5 \text { j. } \\
50 \text { j. Dysport }\end{array}$ & $\begin{array}{l}\text { Botox w porównaniu } \\
\text { z Dysportem }\end{array}$ & $\begin{array}{l}\text { częstość występowania działań niepożądanych: } \\
\text { Botox } 47 \% \text {, Dysport 50\%, najczęstsze działanie } \\
\text { niepożądane - opadanie powiek (brak bliższej analizy) }\end{array}$ \\
\hline $\begin{array}{l}\text { Nussgens } \\
\text { i wsp., } 1997 \\
\text { [37] }\end{array}$ & 212 & $\begin{array}{l}\text { Botox, } \\
\text { średnia dawka 22,7 j. } \\
\text { Dysport, } \\
\text { średnia dawka } 91,5 \mathrm{j} \text {. }\end{array}$ & $\begin{array}{l}\text { Botox w porównaniu } \\
\text { z Dysportem, badanie metodą } \\
\text { podwójnie ślepej próby }\end{array}$ & $\begin{array}{l}\text { objawy niepożądane miejscowe } \\
\text { po podaniu Botoxu - } 17 \% \text { vs } 24 \% \\
\text { po podaniu Dysportu, w tym: ptoza } 1,4 \% \\
\text { po podaniu Botoxu vs } 6,6 \% \text { po podaniu Dysportu }\end{array}$ \\
\hline $\begin{array}{l}\text { Roggenkamper } \\
\text { i wsp., } 2006 \\
\text { [53] }\end{array}$ & 300 & $20,2 \mathrm{j}$. & $\begin{array}{l}\text { Botox w porównaniu } \\
\text { z Xeominem, badanie metodą } \\
\text { podwójnie ślepej próby }\end{array}$ & $\begin{array}{l}\text { Botox: objawy niepożądane wystąpiły łącznie } \\
\text { u } 29 / 152 \text { chorych, w tym: opadanie powiek } 4 \% \text {, } \\
\text { zaburzenia widzenia } 3 \% \text {, ból pleców } 2 \%, \\
\text { osutka } 1 \% \text {, zakażenie górnych dróg oddecho- } \\
\text { wych } 1 \% \text {, obrzęk twarzy } 1 \% \text {, } \\
\text { Xeomin: objawy niepożądane wystąpiły łącznie } \\
\text { u } 31 / 148 \text { leczonych, w tym: opadanie powiek } 6 \% \text {, } \\
\text { zaburzenia widzenia } 1 \% \text {, ból pleców } 1 \%, \\
\text { osutka } 0,5 \% \text {, zakażenie górnych dróg oddecho- } \\
\text { wych } 0,5 \% \text {, obrzęk twarzy } 0,5 \%\end{array}$ \\
\hline
\end{tabular}

w porównaniu z Botoksem) [53]. W badaniu tym wzięło udział 300 pacjentów, stwierdzono jednakową skuteczność obu leków oraz podobną częstość występowania działań niepożądanych (tab. 3.). Efekt działania leków oceniano, używając skali Jankovica oraz skali oceny niesprawności (JRS oraz BSDI). Liczba chorych, u których obserwowano znaczną poprawę, wynosiła 34,9\% w grupie Xeominu w porównaniu z 28,4\% w grupie, która otrzymała Botox (różnica nieistotna statystycznie). Poprawa pojawiała się średnio po 4 dniach i utrzymywała ok. 11 tyg.

Dostępne na rynku preparaty Botox, Xeomine i Dysport mają podobną skuteczność i profil działań niepo- żądanych. Ponadto, zarówno w przypadku kurczu powiek, jak i połowiczego kurczu twarzy na skuteczność działania BTX-A wpływa równiė̇ wybór dawki oraz miejsce podania leku. Zalecenia dotyczące miejsca wstrzyknięcia różnią się także w zależności od preparatu (Botox - przedtarczkowo, Dysport - powyżej, bardziej dystalnie od powieki); porównanie skuteczności i działań niepożądanych dostępnych preparatów utrudniają dodatkowo różne techniki wstrzykiwania (liczba i lokalizacja punktów podania). Zgodnie z wynikami Cakmura i wsp. podanie leku w część przedtarczkową mięśnia okrężnego oka przynosi lepsze efekty niż w część przedprzegrodową, ponadto, dłuższy czas trwa- 
nia poprawy oraz mniejsza liczba działań niepożądanych dodatkowo przemawiają za podaniem leku właśnie w okolicę przedtarczkową [82]. W badaniu retrospektywnym opracowanym przez Bentivoglio i wsp., analizującym skuteczność i bezpieczeństwo długotrwałego leczenia BTX-A (Botox i Dysport), zaobserwowano niewielkie różnice w profilu klinicznym obu leków w zakresie: działań niepożądanych (16,7\% po podaniu Botoksu i $19,7 \%$ po podaniu Dysportu), niepowodzenia leczenia $(6,6 \%$ po podaniu Botoksu i $4,6 \%$ po podaniu Dysportu), nieznacznie dłuższego czasu trwania poprawy po podaniu Botoksu niż po podaniu Dysportu [81]. Odmienna farmakokinetyka, podkreślana przez wymienione różnice, wskazuje, że pomimo tej samej substancji czynnej w obu preparatach należy je traktować jako odmienne leki.

\section{Porównanie preparatów toksyny botulinowej w leczeniu spastyczności}

\section{Spastyczność w przebiegu mózgowego porażenia dziecięcego}

Mózgowe porażenie dziecięce (MPD) jest główną przyczyną niepełnosprawności wśród dzieci i młodzie$\dot{z}$ y. Istotnym elementem obrazu klinicznego MPD jest spastyczność.

Koman i wsp. pierwsi zastosowali BTX-A (Botox) w leczeniu spastyczności związanej z MPD [83]. Wyniki badań przeprowadzonych na małych grupach pacjentów, które zostały opublikowane na początku lat 90. XX w., wykazały, że zarówno Botox, jak i Dysport $[84,85]$ są skuteczne w leczeniu spastyczności mięśnia trójgłowego łydki powodującej końskie ustawienie stopy w fazie podporu. W kolejnych latach pojawity się publikacje przedstawiające wyniki zastosowania BTX-A w leczeniu innych mięśni kończyn dolnych, takich jak mięśnie kulszowo-goleniowe (chód kuczny) czy przywodziciele (chód nożycowy) [86-88]. W tych pierwszych badaniach trudno wykazać istotne różnice pomiędzy preparatami. Zarówno technika wstrzykiwania, jak i skuteczność oraz odsetek działań niepożądanych były podobne. W 1997 r. Forsberg i Tedroff [89] krytycznie odnieśli się do poziomu dowodów przemawiających za stosowaniem BTX-A w leczeniu MPD. Wywołało to ożywioną dyskusję, a po kilku latach zaczęły pojawiać się wyniki lepiej zaplanowanych badań klinicznych potwierdzających skuteczność BTX-A, wśród nich trzy istotne badania z randomizacją dotyczące Dysportu. W pierwszym z nich Ubhi i wsp. wykazali pozytywny wpływ leku zarówno na poziomie struktury (poprawa zgięcia grzbietowego i wzorca chodu), jak i funkcji oraz aktywności (Gross Motor Function Measure - GMFM) [90]. W drugim, Baker i wsp. zbadali zależność skuteczności od dawki leku w leczeniu spastyczności mięśnia brzuchatego łydki u dzieci z obustronnym niedowładem kurczowym i wykazali największy wpływ dawki Dysportu wynoszącej $10 \mathrm{j} . / \mathrm{kg} /$ mięsień [91]. Podobne badanie w grupie dzieci z niedowładem połowiczym przeprowadzili Polak i wsp. [92]. Wykazali oni jednak, że bardziej skuteczna jest dawka 24 j./kg/mięsień. Pojawiło się też wiele publikacji dotyczących Botoksu, w tym dwa istotne badania $z$ randomizacją i z grupą kontrolną potwierdzające skuteczność Botoksu w zakresie długości mięśnia i wzorca chodu $[93,94]$. Ciekawe z punktu widzenia niniejszego opracowania są badania, w których używano zarówno Botoksu, jak i Dysportu jak podają autorzy, preparaty stosowane były zależnie od dostępności [86,88,95-98]. Nie wykazano różnic pomiędzy preparatami, ale żadne $\mathrm{z}$ badań nie było ich porównaniem bezpośrednim (tab. 4.).

Początek nowego wieku przyniósł dynamiczny rozwój zastosowania BTX-A w leczeniu dzieci z MPD. Opublikowano wiele prac opisujących różnorodne aspekty terapii, szczególnie we wskazaniach pozarejestracyjnych. Pomimo tego istnieją obecnie silne dowody jedynie na skuteczność Botoksu i Dysportu w leczeniu spastyczności mięśnia brzuchatego łydki, czyli we wskazaniu, w którym preparaty są zarejestrowane w Polsce. Opublikowano 4 badania klasy I według Amerykańskiej Akademi Neurologii i uzyskano rekomendację A (uznany za bezpieczny i skuteczny) $[90,91,93,94]$. Badania kliniczne dotyczące skuteczności wstrzyknięć do mięśnia brzuchatego łydki zebrano w tab. 4. [85,90-94,96,99-105]. Największym przełomem w terapii MPD wydaje się zastosowanie wielopoziomowych wstrzyknięć poprzedzonych wnikliwą oceną zarówno zaburzeń struktury i funkcji, jak i aktywności oraz zdefiniowaniem celów terapii, w tym także na poziomie uczestnictwa. Po wstrzyknięciach pacjenci objęci są programem usprawniania, stosowane jest odpowiednie zaopatrzenie ortopedyczne, a w razie konieczności także gipsy redresyjne [106]. Takie leczenie przynosi wymierne efekty we wszystkich badanych sferach i zmienia naturalny przebieg choroby $[107,108]$. Właśnie w tym typie leczenia występuje największa różnica pomiędzy preparatami BTX-A. Konieczność ostrzykiwania jednocześnie wielu grup mięśniowych 


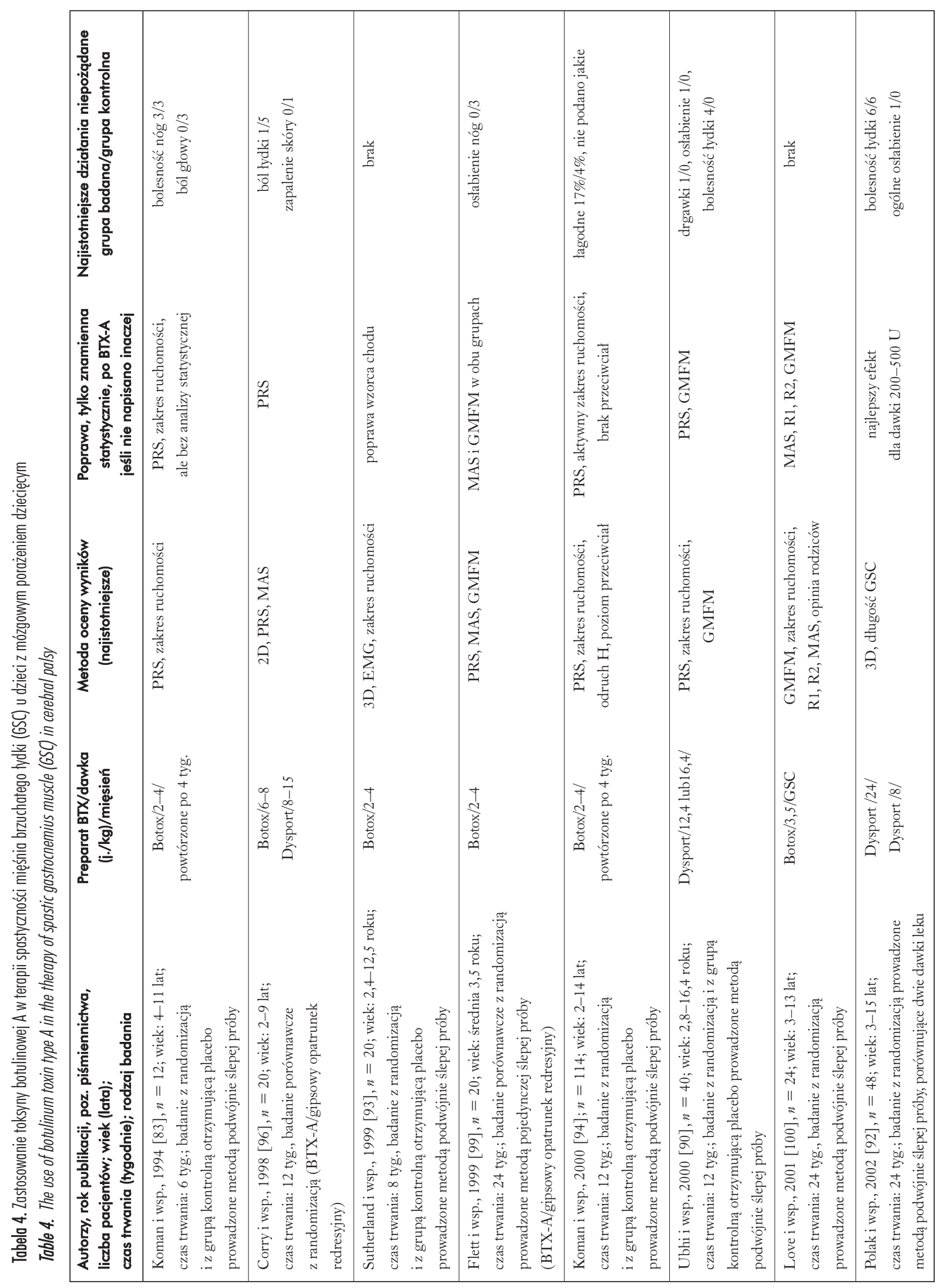




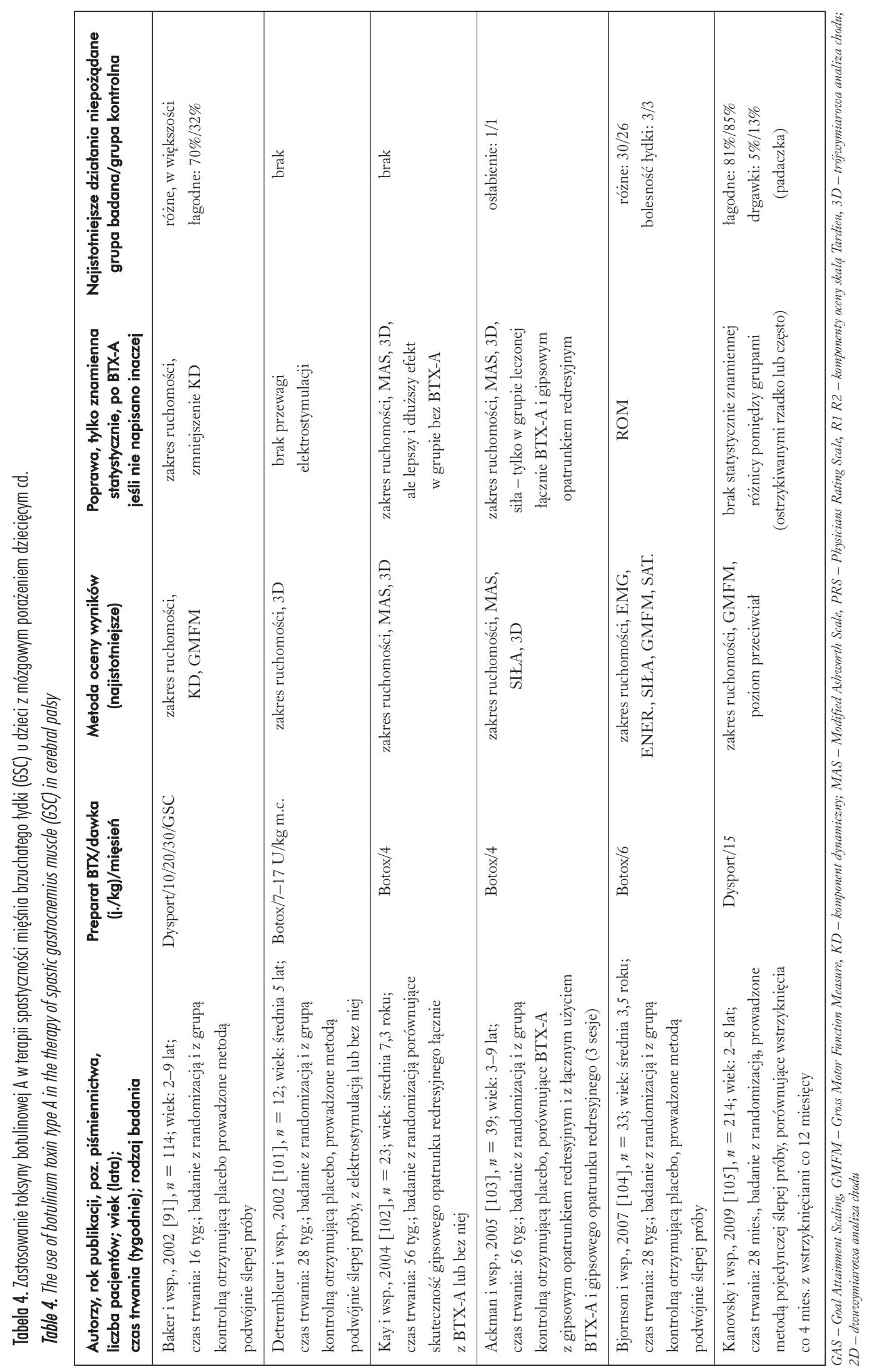


zgodnie z zalecanym dawkowaniem (www.mdvu.org) powoduje zwiększenie dawki całkowitej leku. W przypadku Botoksu dawki te dochodzą do $30 \mathrm{j} . / \mathrm{kg}$ m.c. [109]. Brak dowodów na bezpieczne stosowanie dawek Dysportu większych niż 30 j./kg m.c. ogranicza zastosowanie tego preparatu w leczeniu wielopoziomowym.

Jednym z istotnych zastosowań BTX-A w MPD poza rejestracją jest terapia kończyny górnej. Pomimo rosnącej liczby publikacji skuteczność BTX-A w tym wskazaniu nie została ostatecznie określona. Przykładem są dwie ostatnie prace [110,111], z których pierwsza wykazała brak poprawy na poziomie funkcjonalnym w porównaniu z grupą kontrolną, druga natomiast istotną poprawę zarówno funkcji, jak i aktywności w ocenie rodziców. W tym wskazaniu nie wydaje się, by istniała istotna różnica pomiędzy preparatami, jednak większość opublikowanych wyników badań z randomizacją i z grupą kontrolną dotyczy Botoksu [112,113]. Botox i Dysport nie różnią się profilem bezpieczeństwa w leczeniu spastyczności ograniczonej do pojedynczych grup mięśniowych. Różnice pojawiają się wraz ze zwiększaniem dawki leku i liczby ostrzykiwanych mięśni. Największym dotychczas opracowaniem dotyczącym skuteczności i bezpieczeństwa leczenia dzieci z MPD Dysportem jest retrospektywne badanie Bakheit $\mathrm{i}$ wsp. Wśród 758 pacjentów (1594 sesje) odsetek działań niepożądanych wyniósł $7 \%$. Warto jednak podkreślić, że w grupie, która otrzymała dawki leku większe niż 1000 j. /sesję lub 30 j./kg m.c., odsetek ten wynosił $22 \%$, ponadto, u pacjentów tych wykazano pogorszenie stanu funkcjonalnego [114]. W metaanalizie dotyczącej bezpieczeństwa stosowania Botoksu, Naumann i Jankovic porównali dane z leczenia 245 pacjentów z 229 osobami, które otrzymały placebo [115]. Stwierdzili znamiennie częstsze występowanie $\mathrm{w}$ grupie leczonej jedynie ogniskowego osłabienia, a działanie to można uznać za zamierzone i związane $\mathrm{z}$ mechanizmem działania leku. W najbardziej szczegółowym przeglądzie badań z randomizacją i z grupa kontrolna, Albavera-Hernandez i wsp. [116] wybrali 20 badań $z$ randomizacją i z grupą kontrolną, w których oceniane były działania niepożądane. Wśród nich tylko w czterech stosowano Dysport. Na podstawie tego przeglądu trudno stwierdzić wyraźne różnice pomiędzy preparatami. Warto podkreślić, że w żadnym z czterech badań, w których stosowano Dysport, nie przekroczono dawki 30 j./kg m.c., natomiast dawka Botoksu dochodziła do $20 \mathrm{j}$./kg m.c. Autorzy podkreślają dobry profil bezpieczeństwa leku w badaniach krótkoterminowych i średnioterminowych, pogarszający się jednak wraz z przedłużającym się cza- sem badania. Może to jednak wynikać z przyjętej przez autorów metodologii, a nie rzeczywistego działania BTX-A. Najczęściej spotykane działania niepożądane - złe samopoczucie, senność, objawy grypopodobne, dreszcze, zapalenia gardła, zapalenia dróg oddechowych, drgawki, bolesność kończyn, zaburzenia trzymania moczu, astma - występują wśród populacji dzieci z MPD $\mathrm{i}$ ich pojawienie się w czasie badań długoterminowych wydaje się nieuniknione. Najlepszym przykładem są opublikowane ostatnio wyniki międzynarodowego wieloośrodkowego badania, którego celem było porównanie dwóch sposobów podawania Dysportu (co 4 miesiące lub co rok) - działania niepożądane stwierdzono u $80 \%$ badanych niezależnie od sposobu podawania le$\mathrm{ku}$ [105]. Badanie trwało jednak 28 miesięcy i rejestrowane były wszystkie zdarzenia. Badania dotyczące stosowania wysokich dawek Botoksu koniecznych do leczenia wielopoziomowego nie wykazują istotnego wzrostu działań niepożądanych nawet przy dawkach Botoksu dochodzących do 30 j./kg m.c. i długim czasie stosowania [117-121]. Brak jest wystarczających dowodów na bezpieczeństwo wielopoziomowych wstrzyknięć Dysportu i stosowanie dawek tego leku większych niż 25 j./kg m.c. $[114,121,122]$. Europejski konsensus specjalistów (2006) zaleca używanie maksymalnej dawki 25 j./kg m.c. zarówno dla Dysportu, jak i Botoksu [123].

\section{Leczenie spastyczności u dorosłych}

Najważniejsze przyczyny spastyczności u osób dorosłych to udary mózgu, urazy głowy i rdzenia kręgowego oraz stwardnienie rozsiane. Opublikowany w $2009 \mathrm{r}$. europejski konsensus dotyczący zastosowania toksyny botulinowej w leczeniu spastyczności dorosłych daje dość jasne wytyczne dotyczące zasad leczenia [124]. Nie ma jednak jednoznacznych danych porównujących poszczególne preparaty. Skuteczność Botoksu i Dysportu jest dobrze udokumentowana w licznych badaniach klinicznych, natomiast w przypadku preparatu Xeomin dostępne jest jedno badanie kliniczne $\mathrm{z}$ grupą kontrolną otrzymującą placebo. Ze względu na różne właściwości farmakokinetyczne nie ma prostego przelicznika między liczbą jednostek poszczególnych preparatów w leczeniu spastyczności. Wybór preparatu i dawki powinien być dostosowany do każdego pacjenta oraz nasilenia objawów spastyczności. Zaleca się nieprzekraczanie maksymalnych dawek na sesję: 1500 j. Dysportu i 600 j. Botoksu, oraz nieprzekraczanie maksymalnych dawek w jednym miejscu podania: 125 j. Dysportu i 50 j. Botoksu [124]. Nie ma badań bezpośrednio porównujących poszczególne 
preparaty BTX-A w leczeniu spastyczności ani danych na temat np. dyfuzji czy migracji leku z miejsca podania. Uzyskanie najlepszego efektu z minimalnymi działaniami niepożądanymi jest możliwe, gdy lek zostanie podany bezpośrednio do zajętego mięśnia, co można osiagnać przez zastosowanie takich metod, jak neurostymulacja, elektromiografia czy ultrasonografia. Ma to szczególne znaczenie w sytuacji, gdy podaje się lek do mięśni małych i położonych głęboko [124].

Zgodnie z przyjętą metodologią do analizy włączono najważniejsze publikacje dotyczące leczenia spastyczności (prace prospektywne, wieloośrodkowe, z randomizacją i z grupą kontrolną otrzymującą placebo, obejmujące więcej niz 50 pacjentów). Do oceny skuteczności leczenia używano w tych badaniach zazwyczaj zmodyfikowanej skali Ashwortha, a w niektórych także uproszczonej skali funkcjonalnej (Disability Assessment Score) czy skal globalnych (Patient and Physician Global Rating Scale). W przypadku preparatu Dysport dysponujemy dość dużą liczbą publikacji dotyczących leczenia spastyczności zarówno kończyny górnej, jak i dolnej. Bakheit i wsp. wskazują korzystny efekt obniżenia napięcia mięśniowego przy zastosowaniu preparatu Dysport w dawce $1000 \mathrm{j}$. w leczeniu spastyczności poudarowej kończyny górnej. Efekt utrzymuje się co najmniej 16 tyg., niepowodując przy tym istotnych działań niepożądanych [125]. W kolejnych pracach Bakheit i wsp. donoszą, iz dawka 1000 j. Dysportu jest optymalna do uzyskania jak najlepszej poprawy przy minimalnych działaniach niepożądanych (lepsza niż dawka 1500 j.) $[126,127]$. McCorry w najnowszej pracy na temat leczenia spastyczności poudarowej kończyny górnej za pomoca preparatu Dysport wskazuje na istotna poprawę w napięciu mięśniowym mierzoną za pomocą zmodyfikowanej skali Ashwortha, przy braku istotnej statystycznie poprawy w skalach dotyczących jakości życia, nastroju czy bólu [128]. Na obniżenie napięcia mięśsniowego i bólu kończyny oraz mniejszą zależność od pomocy przy chodzeniu uwagę zwrócili Pittock i wsp. w pracy na temat skuteczności leczenia spastyczności poudarowej kończyny dolnej. Jednocześnie autorzy donoszą, iz dawki preparatu Dysport 1500 j. były skuteczniejsze niż 1000 j., przy braku istotnych działań niepożądanych [129]. Praca Hyman i wsp. dotyczy leczenia spastyczności kończyn dolnych pacjentów ze stwardnieniem rozsianym; dane przedstawione w tej pracy wskazują na dobry efekt terapeutyczny leczenia preparatem Dysport w odniesieniu zarówno do obniżenia napięcia mięśniowego, jak i zwiększenia zakresu ruchów. Zwrócono również uwagę, iż większe dawki preparatu Dys- port (powyżej 1500 j.) powodują ponaddwukrotne zwiększenie działań niepożądanych [130].

Skuteczność preparatu Botox w leczeniu spastyczności kończyny górnej potwierdza wiele publikacji. Korzystny efekt leczenia spastyczności poudarowej w zakresie palców i nadgarstka opisano w pracy Brashaer i wsp. z 2002 r. Stosowano dawki Botoksu wynoszące 200-240 j. Poprawa, utrzymująca się ok. 12 tyg., dotyczyła zarówno redukcji napięcia mięśniowego, jak i niesprawności (Disability Assessment Scale), przy braku istotnych działań niepożądanych [131]. Childers i wsp. w badaniu z 2004 r. wskazują na istotny klinicznie efekt zależny od dawki, dotyczący zmniejszenia napięcia mięśniowego mierzonego w skali Ashwortha, utrzymujący się do 9 tyg. po podaniu leku do zginaczy nadgarstka i stawu łokciowego i do 3 tyg. w przypadku zginaczy palców. Stosowane dawki leku to: 90, 180 i 360 j. preparatu Botox. Nie obserwowano natomiast istotnej statystycznie poprawy w skalach jakości życia, niesprawności i bólu. Nieco większa była liczba działań niepożądanych w grupie osób leczonych preparatem Botox w stosunku do placebo [132]. W pracy Richardson i wsp. z 2000 r., w której analizowano leczenie Botoksem spastyczności kończyny górnej i dolnej, której przyczyną były różne stany chorobowe: udary, urazy głowy i rdzenia, guzy, porażenie mózgowe, encefalopatia niedokrwienna, wartość dawki podawanej do pojedynczego mięśnia wahała się między 20 a 100 j. Uzyskano poprawę zarówno w skali Ashwortha, jak i w skalach funkcjonalnych; efekt utrzymywał się do 12 tyg. od podania leku. Nie odnotowano istotnych działań niepożądanych [133]. Ostatnio opublikowano badanie dotyczace preparatu Xeomin w leczeniu poudarowej spastyczności kończyny górnej. Wyniki wskazują na istotną poprawę w zakresie skali Ashwortha w porównaniu z osobami otrzymującymi placebo. Dawki były dostosowywane do potrzeb chorego, średnia dawka wyniosła $320 \mathrm{j}$. Czas istotnej statystycznie poprawy wynosił 12 tyg. Liczba działań niepożądanych była niewielka i porównywalna w obu grupach. U żadnej osoby nie wykryto przeciwciał neutralizujących [134].

Zestawienie najistotniejszych parametrów, takich jak czas poprawy i zakres działań niepożądanych w stosunku do placebo dla poszczególnych preparatów (zsumowane wartości z wielu prac), przedstawia tab. 5. Przeprowadzone badania wykazały skuteczność leczenia spastyczności kończyny górnej za pomocą różnych preparatów BTX-A, przy czym należy stwierdzić, że poszczególne preparaty różnią się między sobą, a skala tych różnic w chwili obecnej jest trudna do oceny ze względu na brak 
Tabela 5. Zebrane dane na temat spastyczności poudarowej kończyny górnej wg artykutów przedstawianych w pracy: Dysport [126-128], Xeomin [134], Botox [131,132] Table 5. Summary of data on post-stroke spasticity of the upper limb according to presented studies: Dysport [126-128], Xeomin [134], Botox [131, 132]

\begin{tabular}{|lccc|}
\hline $\begin{array}{l}\text { Preparaty toksyny } \\
\text { botulinowej } \\
\text { typu A }\end{array}$ & $\begin{array}{c}\text { Liczba wszystkich pacjentów } \\
\text { objętych analizowanymi } \\
\text { badaniami (liczba badań) }\end{array}$ & $\begin{array}{c}\text { Maksymalny czas utrzymujq̨cej się } \\
\text { istotnej statystycznie poprawy } \\
\text { w skali Ashwortha }\end{array}$ & $\begin{array}{c}\text { Procent, o jaki liczba działań niepożqdanych } \\
\text { była większa w grupie leczonej toksynq } \\
\text { botulinowq typu A w stosunku do placebo }\end{array}$ \\
\hline Dysport & $289(4)$ & $12-20$ tyg. & $0-24 \%$ \\
\hline Xeomin & $148(1)$ & 12 tyg. & $2 \%$ \\
\hline Botox & $143(2)$ & $9-12$ tyg. & $0-22 \%$ \\
\hline
\end{tabular}

badań bezpośrednich. Nie ma jednoznacznie pozytywnych wyników dotyczących leczenia spastyczności kończyny dolnej za pomocą BTX-A i w tej chwili rejestracja tego sposobu leczenia istnieje tylko w niewielu krajach.

\section{Podsumowanie}

Liczba opublikowanych badań może skłaniać do porównań bezpośrednich i pośrednich między dostępnymi preparatami BTX-A. Badania te przynoszą jednak zróżnicowane wyniki, które pokazują w sposób jednoznaczny, że nie mamy tu do czynienia z lekami generycznymi, a zupełnie innymi, różniącymi się istotnie preparatami. Łączy je przynależność do serotypu A oraz ostateczny mechanizm działania hamujący uwalnianie acetylocholiny z zakończeń presynaptycznych. Dzieli wszystko inne: budowa, ilość toksyny w ampułce, ilość białek kompleksujących, sposób produkcji, dopuszczalne wahania w sile działania między ampułkami, sposób oceny siły działania jednej jednostki, efekty w badaniach klinicznych, profil działań niepożądanych, zalecane przez producenta rozcieńczenia czy schematy ostrzyknięć. Dyskusja nad porównywaniem biorównoważności dawek prowadzi do wniosków, że są one w istocie trudne do porównania i powinny być traktowane jako „niezamienialne”, a jedynie pewne granice bezpieczeństwa i skuteczności wyznaczone przez badania kliniczne oraz doświadczenie lekarza mogą być wskazówkami w codziennej praktyce klinicznej. Preparaty BTX-A należy traktować zatem jako różne leki i zachować szczególną ostrożność przy ich zamiennym stosowaniu oraz podawaniu większych dawek.

\section{Oświadczenie}

Jarosław Sławek jest wykładowcą i prowadzi warsztaty na konferencjach organizowanych przez firmy Allergan, Ipsen i Merz. Żadna z firm nie ingerowała w treść artykułu. Pozostali autorzy zgłaszają brak konfliktu interesów.

\section{Piśmiennictwo}

1. Hunt T., Clarke K. Potency of the botulinum toxin product CNBTX-A significantly exceeds labeled units in standard potency test. J Am Acad Dermatol 2008; 58: 517-518.

2. Hill K.K., Smith T.J., Helma C.H. i wsp. Genetic diversity among Botulinum Neurotoxin-producing clostridial strains. J Bacteriol 2007; 189: 818-832.

3. Smith T.J., Lou J., Geren I.N. i wsp. Sequence variation within botulinum neurotoxin serotypes impacts antibody binding and neutralization. Infect Immun 2005; 73: 5450-5457.

4. Brashear A. Clinical comparisons of botulinum neurotoxin formulations. Neurologist 2008; 14: 289-298.

5. Inoue K., Fujinaga Y., Watanabe T. i wsp. Molecular composition of clostridium botulinum type A progenitor toxins. Infect Immun 1996; 64: 1589-1594.

6. Currà A., Trompetto C., Abbruzzese G. i wsp. Central effects of botulinum toxin type A: evidence and supposition. Mov Disord 2004; 19 (Suppl 8): S60-S64.

7. Hunt T., Clarke K., Rupp D. i wsp. Secondary cleavage of a fluorescently labeled SNAP-25 substrate by Xeomins drug product. Toxicon 2008; 51: 13.

8. Durham P.L., Cady R., Cady R. Regulation of calcitonin gene related peptide secretion from trigeminal nerve cells by botulinum toxin type A: implications for migraine therapy. Headache 2004; 44: 35-42.

9. Rapp D.E., Turk K.W., Bales G.T. i wsp. Botulinum toxin type a inhibits calcitonin gene-related peptide release from isolated rat bladder. $J$ Urol 2006; 175: 1138-1142.

10. Smith C.P., Gangitano D.A., Munoz A. i wsp. Botulinum toxin type A normalizes alterations in urothelial ATP and NO release induced by chronic spinal cord injury. Neurochem Int 2008; 52: 1068-1075.

11. Morenilla-Palao C., Planells-Cases R., García-Sanz N. i wsp. Regulated exocytosis contributes to protein kinase $\mathrm{C}$ potentiation of vanilloid receptor activity. J Biol Chem 2004; 279: 25665-25672.

12. Giannantoni A., Di Stasi S.M., Nardicchi V. i wsp. Botulinum-A toxin injections into the detrusor muscle decrease nerve growth factor bladder tissue levels in patients with neurogenic detrusor overactivity. $J$ Urol 2006; 175: 2341-2344. 
13. Chuang Y.C., Yoshimura N., Huang C.C. i wsp. Intraprostatic botulinum toxin a injection inhibits cyclooxygenase-2 expression and suppresses prostatic pain on capsaicin induced prostatitis model in rat. J Urol 2008; 180: 742-748.

14. Carli L., Montecucco C., Rossetto O. An histological assessment of diffusion of different botulinum neurotoxin type A formulations injected in the mice leg. Toxicon 2008; 51 : 9.

15. Cliff S.H., Judodihardjo H., Eltringham E. Different formulations of botulinum toxin type A have different migration characteristics: a double-blind, randomized study. J Cosmet Dermatol 2008; 7: 50-54.

16. Johnson E.A., Bradshaw M. Clostridium botulinum and its neurotoxins: a metabolic and cellular perspective. Toxicon 2001; 39: 1703-1722.

17. Miyata K., Yoneyama T., Suzuki T. i wsp. Expression and stability of the nontoxic component of the botulinum toxin complex. Biochem Biophys Res Com 2009; 384: 126-130.

18. Chen F., Kuziemko G.M., Stevens R.C. Biophysical characterization of the stability of the 150-kilodalton botulinum toxin, the nontoxic component, and the 900-kilodalton botulinum toxin complex species. Infect Immun 1998; 66: 2420-2425.

19. Schantz E.J., Johnson E.A. Properties and use of botulinum toxin and other microbial neurotoxins in medicine. Microbiol Rev 1992; 56: 80-99.

20. Shimizu G., Rupp D., Tam K. i wsp. Characterization of timedependent enzymatic profiles under various liquid conditions for 150 and $900 \mathrm{kDa}$ botulinum Type-A neurotoxins. Toxicon 2008; 51:21.

21. Grein S., Mander G.J., Taylor H.V. Xeomins is stable without refrigeration: Complexing proteins are not required for stability of botulinum neurotoxin type A preparations. Toxicon 2008; 51: 13.

22. Sesardic D., Leung T., Gaines Das R. Role for standards in assays of botulinum toxins: international collaborative study of three preparations of botulinum type A toxin. Biologicals 2003; 31: 265-276.

23. Pearce L.B., Borodic G.E., Johnson E.A. i wsp. The median paralysis unit: a more pharmacologically relevant unit of biologic activity for botulinum toxin. Toxicon 1995; 33: 217-227.

24. Aoki K.R., Satorius A., Ardila C. i wsp. Pharmacology of BOTOX, Dysport, Myobloc and BTX-A in animal models of efficacy and safety. Neurotoxin Res 2006; 9: 236.

25. Brown M., Satorius A., Ardila C. i wsp. Xeomins displays lower potency and is neutralized by anti-BOTOXs antibodies. Toxicon 2008; 51: 9.

26. Kim S.B., Ban B., Jung K.S. i wsp. A comparative study of botulinum neurotoxin preparations; Botoxs, Dysports, and Neuronoxs using digit abduction scoring assai. Toxicon 2008;51: 15 .

27. Pickett A. Dysport: Pharmacological properties and factors that influence toxin action. Toxicon 2009; 54: 683-689.

28. Auguet M., Favre-Guilmard C., Chabrier P.-E. Analgesic effects of Botulinum toxin $\mathrm{A}$ in antiinflammatory pain model in rats: Comparison of Dysports and Botoxs; synergistic interaction with morphine. Toxicon 2008; 51: 9.

29. Dressler D., Mander G.J., Fink K. Equivalent potency of Xeomins and BOTOXs. Toxicon 2008; 51: 10.

30. Cheng L.W., Onisko B., Johnson E.A. i wsp. Effects of purification on the bioavailability of botulinum neurotoxin type A. Toxicology 2008; 249: 123-129.

31. Aoki K.R., Ranoux D., Wissel J. Using translational medicine to understand clinical differences between botulinum toxin formulations. Eur J Neurol 2006; 13: 10-19.

32. Aoki K.R., Francis J., Reynolds H. i wsp. Comparison of the therapeutic windows of different botulinum neurotoxin preparations in an animal model. Neurol 2003; 60 (Suppl 1): A212-A213.

33. Tang-Lui D.D.-S., Aoki K.R., Dolly J.O. i wsp. Intramuscular injection of $125 \mathrm{I}$-botulinum neurotoxincomplex versus 125I-botulinum-free neurotoxin: time course of tissue distribution. Toxicon 2003; 42: 461-469.

34. Wolfarth K., Kampe K., Bigalke H. Pharmacokinetic properties of different formulations of botulinum neurotoxin type A. Mov Disord 2004; 19 (Suppl 8): S65-S67.

35. Gracies J.M., Lugassy M., Weisz D.J. i wsp. Botulinum toxin dilution and endplate targetting in spasticity: a doubleblind controlled study. Arch Phys Med Rehabil 2009; 90: 9-16.

36. Durif F. Clinical bioequivalence of the current commercial preparations of botulinum toxin. Eur J Neurol 1995; 2: 17-18.

37. Nüssgens Z., Roggenkamper P. Comparison of two botulinumtoxin preparations in the treatment of essential blepharospasm. Graefes Arch Clin Exp Ophtalmol 1997; 235: 197-199.

38. Sampaio C., Ferreira J.J., Simões F. i wsp. DYSBOT: a single-blind, randomized parallel study to determine whether any differences can be detected in the efficacy and tolerability of two formulations of botulinum toxin type A - Dysport and Botox - assuming a ratio of 4:1. Mov Disord 1997; 12: 1013-1018.

39. Odergren T., Hjaltason H., Kaakola S. i wsp. A double-blind, randomised, parallel group study to investigate the dose equivalence of Dysport and Botox in the treatment of cervical dystonia. $J$ Neurol Neurosurg Psychiatry 1998; 64: 6-12.

40. Bihari K. Safety, effectiveness, and duration of effect of BOTOX after switching from Dysport for blepharospasm, cervical dystonia, and hemifacial spasm dystonia, and hemifacial spasm. Curr Med Res Opin 2005; 21: 433-438.

41. Ranoux D., Gury C., Fondarai J. i wsp. Respective potencies of Botox and Dysport: a double blind, randomised, crossover study in cervical dystonia. $J$ Neurol Neurosurg Psychiatry 2002; 72: 459-462.

42. Sampaio C., Costa J., Ferreira J.J. Clinical comparability of marketed formulations of botulinum toxin. Mov Disord 2004; 19 (Suppl 8): S129-S136.

43. Talarico-Filho S., Mendonça D.O., Nascimento M. i wsp. A double-blind, randomized, comparative study of two type A botulinum toxins in the treatment of primary axillary hyperhidrosis. Dermatol Surg 2007; 33 (1 Spec No): S44-S50. 
44. Simonetta Moreau M., Cauhepe C., Magues J.P. i wsp. A double-blind, randomized, comparative study of Dysport vs. Botox in primary palmar hyperhidrosis. $\mathrm{Br} J$ Dermatol 2003; 149: 1041-1045.

45. Lowe P., Patnaik R., Lowe N. Comparison of two formulations of botulinum toxin type $\mathrm{A}$ for the treatment of glabellar lines: a double-blind, randomized study. $J$ Am Acad Dermatol 2006; 55: 975-980.

46. Marchetti A., Magar R., Findley L. i wsp. Retrospective evaluation of the dose of Dysport and BOTOX in the management of cervical dystonia and blepharospasm: the REAL DOSE study. Mov Disord 2005; 20: 937-944.

47. Wolfarth K., Goschel H., Frevert J. i wsp. Botulinum A toxins: units versus units. Arch Pharmacol 1997; 355: 335-340.

48. Wolfarth K., Schwandt I., Wegner F. i wsp. Biological activity of two botulinum toxin type A complexes (Dysport and Botox) in volunteers. A double blind, randomized, dose ranging study. J Neurol 2008; 25 5: 1932-1939.

49. Wohlfarth K., Sycha T., Ranoux D. i wsp. Dose equivalence of two commercial preparations of botulinum neurotoxin type A: time for a reassessment? Curr Med Res Opin 2009; 25: 1573-1584.

50. Kranz G., Haubenberger D., Voller B. i wsp. Respective potencies of Botox and Dysport in a human skin model: a randomized, double-blind study. Mov Disord 2009; 24: 231-236.

51. Chapman M.A., Baron R., Tanis D.C. i wsp. Comparison of botulinum neurotoxin preparations for treatment of cervical dystonia. Clin Ther 2007; 29: 1325-1327.

52. Benecke R., Jost W.H., Kanovsky P. i wsp. A new botulinum toxin type A free of complexing proteins for treatment of cervical dystonia. Neurology 2005; 64: 1949-1951.

53. Roggenkämper P., Jost W.H., Bihari K. i wsp. Efficacy and safety of a new botulinum toxin type A free of complexing proteins in the treatment of blepharospasm. $J$ Neural Transm 2006; 113: 303-312.

54. Jost W.H., Kohl A., Brinkmann S. i wsp. Efficacy and tolerability of botulinum toxin type A free of complexing proteins (NT201) compared with commercially available botulinum toxin type A (Botox) in healthy volunteers. J Neural Trans 2005; 112: 905-913.

55. Hunt T., Clarke K. Potency evaluation of a formulated drug product containing $150-\mathrm{kD}$ neurotoxin type A. Clin Neuropharmacol 2009; 32: 28-31.

56. Sesardic D., Jones R.G., Leung T. i wsp. Detection of antibodies against botulinum toxins. Mov Disord 2004; 19 (Suppl 8): S85-S91.

57. Hanna P.A., Jankovic J., Vincent A. Comparison of mouse bioassay and immune-precipitation assay for botulinum toxin antibodies. J Neurol Neurosurg Psychiatry 1999; 66: 612-616.

58. Borodic G.E., Johnson E., Goodnough M. i wsp. Botulinum toxin therapy, immunologic resistance, and problems with available materials. Neurology 1996; 46: 26-29.

59. Zuber M., Sebald M., Bathien N. i wsp. Botulinum antibodies in dystonic patients treated with type A botulinum toxin: frequency and significance. Neurology 1993; 43: 1715-1718.

60. Greene P.E., Fahn S., Diamond B. Development of resistance to botulinum toxin type A in patients with torticollis. Mov Disord 1994; 9: 213-217.

61. Göschel H., Wohlfarth K., Frevert J. i wsp. Botulinum toxin A therapy: neutralizing and nonneutralizing Abs - therapeutic consequences. Exp Neurol 1997; 147: 96-102.

62. Jankovic J., Schwartz K. Response and immunoresistance to botulinum toxin injections. Neurology 1995; 45: 1743-1746.

63. Aoki K.R. A comparison of the safety margins of botulinum neurotoxin serotypes $\mathrm{A}, \mathrm{B}$ and $\mathrm{F}$ in mice. Toxicon 2001; 39: 1815-1920.

64. Jankovic J., Vuong K.D., Ahsan J. Comparison of efficacy and immunogenicity of original versus current botulinum toxin in cervical dystonia. Neurology 2003; 60: 1186-1188.

65. Brin M.F., Comella C.L., Jankovic J. i wsp. Long-term treatment with botulinum toxin type $\mathrm{A}$ in cervical dystonia has low immunogenicity by mouse protection assay. Mov Disord 2008; 23: 1353-1360.

66. Yablon S.A., Brashear A., Gordon M.F. i wsp. Formation of neutralizing antibodies in patients receiving botulinum toxin type A for treatment of poststroke spasticity: a pooled-data analysis of three clinical trials. Clin Ther 2007; 29: 683-690.

67. Mohammadi B., Buhr N., Bigalke H. i wsp. A long-term follow-up of botulinum toxin A in cervical dystonia. Neurol Res 2009; 31: 463-466.

68. Factor S.A., Molho E.S., Evans S. i wsp. Efficacy and safety of repeated doses of botulinum toxin type B in type A resistant and responsive cervical dystonia. Mov Disord 2005; 20: 1152-1160.

69. Jankovic J., Hunter C., Dolimbek B.Z. i wsp. Clinico-immunologic aspects of botulinum toxin type B treatment of cervical dystonia. Neurology 2006; 67: 2233-2235.

70. Simpson D.M., Blitzer A., Brashear A. i wsp. Therapeutics and Technology Assessment Subcommittee of the American Academy of Neurology. Assessment: Botulinum neurotoxin for the treatment of movement disorders (an evidence-based review): report of the Therapeutics and Technology Assessment Subcommittee of the American Academy of Neurology. Neurology 2008; 70: 1699-1706.

71. Costa J., Espírito-Santo C., Borges A. i wsp. Botulinum toxin type A therapy for cervical dystonia. Cochrane Database Syst Rev 2005; 1: CD004315.

72. Jankovic J., Schwartz K.S. Clinical correlates of response to botulinum toxin injections. Arch Neurol 1991; 48: 1253-1256.

73. Tsui J.K., Eisen A., Stoessl A.J. i wsp. Double-blind study of botulinum toxin in spasmodic torticollis. Lancet 1986; 2: 245-247.

74. Jankovic J. Treatment of cervical dystonia with botulinum toxin. Mov Disord 2004; 19 (Suppl 8): S109-S115.

75. Jankovic J., Orman J. Botulinum A toxin for cranial-cervical dystonia: a double-blind, placebo-controlled study. Neurology 1987; 37: 616-623. 
76. Grandas F., Elston J., Quinn N. i wsp. Blepharospasm: a review of 264 patients. I Neurol Neurosurg Psychiatry 1988; 51: 767-772.

77. Jankovic J., Schwartz K., Donovan D.T. Botulinum toxin treatment of cranial-cervical dystonia, spasmodic dysphonia, other focal dystonias and hemifacial spasm. J Neurol Neurosurg Psychiatry 1990; 53: 633-639.

78. Park Y.C., Lim J.K., Lee D.K. i wsp. Botulinum a toxin treatment of hemifacial spasm and blepharospasm. J Korean Med Sci 1993; 8: 334-340.

79. Truong D., Comella C., Fernandez H.H. i wsp. Efficacy and safety of purified botulinum toxin type A (Dysport) for the treatment of benign essential blepharospasm: a randomized, placebo-controlled, phase II trial. Parkinsonism Relat Disord 2008; 14: 407-414.

80. Kenney C., Jankovic J. Botulinum toxin in the treatment of blepharospasm and hemifacial spasm. J Neural Transm 2008; 115: 585-591.

81. Bentivoglio R., Fasano A., Ialongo T. i wsp. Fifteen-year experience in treating blepharospasm with botox or dysport: same toxin, two drugs. Neurotox Res 2009; 15: 224-231.

82. Cakmur R., Ozturk V., Uzunel F. i wsp. Comparison of preseptal and pretarsal injections of botulinum toxin in the treatment of blepharospasm and hemifacial spasm. J Neurol 2002; 249: 64-68.

83. Koman L.A., Mooney J.F. 3rd, Smith B. i wsp. Management of cerebral palsy with botulinum-A toxin: preliminary investigation. J Pediatr Orthop 1993; 13: 489-495.

84. Cosgrove A.P., Corry I.S., Graham H.K. Botulinum toxin in the management of the lower limb in cerebral palsy. Dev Med Child Neurol 1994; 36: 386-396.

85. Koman L.A., Mooney J.F. 3rd, Smith B.P. i wsp. Management of spasticity in cerebral palsy with botulinum toxin A: report of preliminary randomized double blind trial. J Pediatr Orthop 1994; 14: 299-303.

86. Corry I.S., Cosgrove A.P., Duffy C.M. i wsp. Botulinum toxin A in hamstring spasticity. Gait Posture 1999; 10: 206-210.

87. Mall V., Heinen F., Kirschner J. i wsp. Evaluation of botulinum toxin A therapy in children with adductor spasm by gross motor function measure. $J$ Child Neurol 2000; 15: 214-217.

88. Thompson N.S., Baker R.J., Cosgrove A.P. i wsp. Musculoskeletal modelling in determining the effect of botulinum toxin on the hamstrings of patients with crouch gait. Dev Med Child Neurol 1998; 40: 622-625.

89. Forssberg H., Tedroff K.B. Botulinum toxin treatment in cerebral palsy: intervention with poor evaluation? Dev Med Child Neurol 1997; 39: 635-640.

90. Ubhi T., Bhakta B.B., Ives H.L. i wsp. Randomised double blind placebo controlled trial of the effect of botulinum toxin on walking in cerebral palsy. Arch Dis Child 2000; 83: 481-487.

91. Baker R., Jasinski M., Maciag-Tymecka I. i wsp. Botulinum toxin treatment of spasticity in diplegic cerebral palsy: a randomized, double-blind, placebo controlled, dose-ranging study. Dev Med Child Neurol 2002; 44: 666-675.
92. Polak F., Morton R., Ward C. i wsp. Double-blind comparison study of two doses of botulinum toxin A injected into calf muscles in children with hemiplegic cerebral palsy. Dev Med Child Neurol 2002; 44: 551-555.

93. Sutherland D.H., Kaufman K.R., Wyatt M.P. i wsp. Doubleblind study of botulinum A toxin injections into the gastrocnemius muscle in patients with cerebral palsy. Gait Posture 1999; 10: 1-9.

94. Koman L.A., Mooney J.F. 3rd, Smith B.P. i wsp. Botulinum toxin type A neuromuscular blockade in the treatment of lower extremity spasticity in cerebral palsy: a randomized, double-blind, placebo-controlled trial. BOTOX Study Group. J Pediatr Orthop 2000; 20: 108-115.

95. Corry I.S., Cosgrove A.P., Walsh E.G. i wsp. Botulinum toxin $\mathrm{A}$ in the hemiplegic upper limb: a double-blind trial. Dev Med Child Neurol 1997; 39: 185-193.

96. Corry I.S., Cosgrove A.P., Duffy C.M. i wsp. Botulinum toxin A compared with stretching casts in the treatment of spastic equinus: a randomised prospective trial. $J$ Pediatr Orthop 1998; 18: 304-311.

97. Eames N.W., Baker R., Hill N. i wsp. The effect of botulinum toxin $\mathrm{A}$ on gastrocnemius length: magnitude and duration of response. Dev Med Child Neurol 1999; 41: 226-232.

98. Fehlings D., Rang M., Glazier J. i wsp. An evaluation of botulinum-A toxin injections to improve upper extremity function in children with hemiplegic cerebral palsy. $J$ Pediatr 2000; 137: 331-337.

99. Flett P.J., Stern L.M., Waddy H. i wsp. Botulinum toxin A versus fixed cast stretching for dynamic calf tightness in cerebral palsy. J Paediatr Child Health 1999; 35: 71-77.

100. Love S.C., Valentine J.P., Blair E.M. i wsp. The effect of botulinum toxin type $\mathrm{A}$ on the functional ability of the child with spastic hemiplegia a randomized controlled trial. Eur J Neurol 2001; 8 (Suppl 5): 50-58.

101. Detrembleur C., Lejeune T.M., Renders A. i wsp. Botulinum toxin and short term electrical stimulation in the treatment of equinus in cerebral palsy. Mov Disord 2002; 17: 162-169.

102. Kay R.M., Rethlefsen S.A., Fern-Buneo A. i wsp. Botulinum toxin as an adjunct to serial casting treatment in children with cerebral palsy. J Bone Joint Surg Am 2004; 86-A: 2377-2384.

103. Ackman J.D., Russman B.S., Thomas S.S. i wsp. Comparing botulinum toxin A with casting for treatment of dynamic equinus in children with cerebral palsy. Dev Med Child Neurol 2005; 47: 620-627.

104. Bjornson K., Hays R., Graubert C. i wsp. Botulinum toxin for spasticity in children with cerebral palsy: a comprehensive evaluation. Pediatrics 2007; 120: 49-58.

105. Kanovský P., Bares M., Severa S. i wsp. Long-term efficacy and tolerability of 4 monthly versus yearly botulinum toxin type A treatment for lower-limb spasticity in children with cerebral palsy. Dev Med Child Neurol 2009; 51: 436-445.

106. Desloovere K., Molenaers G., Jonkers I. i wsp. A randomized study of combined botulinum toxin type A and casting in the ambulant child with cerebral palsy using objective outcome measures. Eur J Neurol 2001; 8 (Suppl 5): 75-87. 
107. Molenaers G., Desloovere K., Fabry G. i wsp. The effects of quantitative gait assessment and botulinum toxin a on musculoskeletal surgery in children with cerebral palsy. J Bone Joint Surg Am 2006; 88: 161-170.

108. Scholtes V.A., Dallmeijer A.J., Knol D.L. i wsp. The combined effect of lower limb multilevel botulinum toxin type a and comprehensive rehabilitation on mobility in children with cerebral palsy: a randomized clinical trial. Arch Phys Med Rehabil 2006; 87: 1551-1558.

109. Molenaers G., Desloovere K., De Cat J. i wsp. Single event multilevel botulinum toxin type A treatment and surgery: similarities and differences. Eur J Neurol 2001; 8 (Suppl 5): 88-97.

110. Rameckers E.A., Speth L.A., Duysens J. i wsp. Botulinum toxin-a in children with congenital spastic hemiplegia does not improve upper extremity motor-related function over rehabilitation alone: a randomized controlled trial. Neurorehabil Neural Repair 2009; 23: 218-225.

111. Olesch C.A., Greaves S., Imms C. i wsp. Repeat botulinum toxin-A injections in the upper limb of children with hemiplegia: a randomized controlled trial. Dev Med Child Neurol 2009 (in press).

112. Reeuwijk A., van Schie P.E., Becher J.G. i wsp. Effects of botulinum toxin type $\mathrm{A}$ on upper limb function in children with cerebral palsy: a systematic review. Clin Rehabil 2006; 20: 375-387.

113. Sakzewski L., Ziviani J., Boyd R. Systematic review and meta-analysis of therapeutic management of upper-limb dysfunction in children with congenital hemiplegia. Pediatrics 2009; 123: e1111-e1122.

114. Bakheit A.M., Severa S., Cosgrove A. i wsp. Safety profile and efficacy of botulinum toxin A (Dysport) in children with muscle spasticity. Dev Med Child Neurol 2001; 43: 234-238.

115. Naumann M., Jankovic J. Safety of botulinum toxin type A: a systematic review and meta analysis. Curr Med Res Opin 2004; 20: 981-990.

116. Albavera-Hernández C., Rodríguez J.M., Idrovo A.J. Safety of botulinum toxin type A among children with spasticity secondary to cerebral palsy: a systematic review of randomized clinical trials. Clin Rehabil 2009; 23: 394-407.

117. Heinen F., Schroeder A.S., Fietzek U. i wsp. When it comes to botulinum toxin, children and adults are not the same: multimuscle option for children with cerebral palsy. Mov Disord 2006; 21: 2029-2030.

118. Willis A.W., Crowner B., Brunstrom J.E. i wsp. High dose botulinum toxin A for the treatment of lower extremity hypertonicity in children with cerebral palsy. Dev Med Child Neurol 2007; 49: 818-822.

119. Goldstein E.M. Safety of high-dose botulinum toxin type A therapy for the treatment of pediatric spasticity. J Child Neurol 2006; 21: 189-192.

120. Kolaski K., Ajizian S.J., Passmore L. i wsp. Safety profile of multilevel chemical denervation procedures using phenol or botulinum toxin or both in a pediatric population. Am J Phys Med Rehabil 2008; 87: 556-566.
121. Naumann M., Albanese A., Heinen F. i wsp. Safety and efficacy of botulinum toxin type A following long-term use. Eur J Neurol 2006; 13 (Suppl 4): 35-40.

122. Mohamed K.A., Moore A.P., Rosenbloom L. Adverse events following repeated injections with botulinum toxin A in children with spasticity. Dev Med Child Neurol 2001; 43: 791.

123. Heinen F., Molenaers G., Fairhurst C. i wsp. European consensus table 2006 on botulinum toxin for children with cerebral palsy. Eur J Paediatr Neurol 2006; 10: 215-225.

124. Wissel J., Ward A.B., Erztgaard P. i wsp. European consensustable on the use of botulinum toxin type A in adult spasticity. J Rehabil Med 2009; 41: 13-25.

125. Bakheit A.M., Pittock S., Moore A.P. i wsp. A randomized, double-blind, placebo-controlled study of the efficacy and safety of botulinum toxin type A in upper limb spasticity in patients with stroke. Eur J Neurol 2001; 8: 559-565.

126. Bakheit A.M., Fedorova N.V., Skoromets A.A. i wsp. The beneficial antispasticity effect of botulinum toxin type $\mathrm{A}$ is maintained after repeated treatment cycles. $J$ Neurol Neurosurg Psychiatry 2004; 75: 1558-1561.

127. Bakheit A.M., Thilmann A.F., Ward A.B. i wsp. A randomized, double-blind, placebo-controlled, doseranging study to compare the efficacy and safety of three doses of botulinum toxin type A (Dysport) with placebo in upper limb spasticity after stroke. Stroke 2000; 31: 2402-2406.

128. McCorry P., Turner-Stokes L., Baguley I.J. i wsp. Botulinum toxin A for treatment of upper limb spasticity following stroke: a multi-centre randomized placebo-controlled study of the effects on quality of life and other personcentred outcomes. J Rehabil Med 2009; 41: 536-544.

129. Pittock S.J., Moore A.P., Hardiman O. i wsp. A doubleblind randomised placebo-controlled evaluation of three doses of botulinum toxin type A (Dysport) in the treatment of spastic equinovarus deformity after stroke. Cerebrovasc Dis 2003; 15: 289-300.

130. Hyman N., Barnes M., Bhakta B. i wsp. Botulinum toxin (Dysport) treatment of hip adductor spasticity in multiple sclerosis: a prospective, randomised, double blind, placebo controlled, dose ranging study. J Neurol Neurosurg Psychiatry 2000; 68: 707-712.

131. Brashear A., Gordon M.F., Elovic E. i wsp.; Botox PostStroke Spasticity Study Group. Intramuscular injection of botulinum toxin for the treatment of wrist and finger spasticity after a stroke. $N$ Engl J Med 2002; 347: 395-400.

132. Childers M.K., Brashear A., Jozefczyk P. i wsp. Dosedependent response to intramuscular botulinum toxin type A for upper-limb spasticity in patients after a stroke. Arch Phys Med Rehabil 2004; 85: 1063-1069.

133. Richardson D., Sheean G., Werring D. i wsp. Evaluating the role of botulinum toxin in the management of focal hypertonia in adults. $J$ Neurol Neurosurg Psychiatry 2000; 69: 499-506.

134. Kanovský P., Sławek J., Denes Z. i wsp. Efficacy and safety of botulinum neurotoxin NT 201 in poststroke upper limb spasticity. Clin Neuropharmacol 2009; 32: 259-265. 